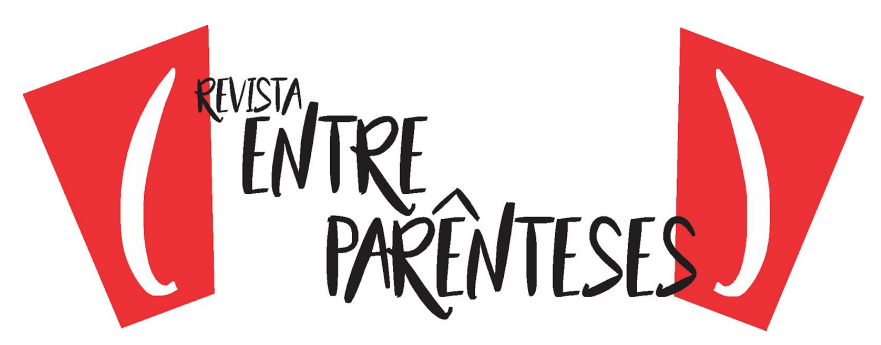

\title{
LITERATURA E CINEMA: PROPOSTA DE UMA LEITURA DIALÓGICA INTERTEXTUAL COMPARATIVA DE DOM QUIXOTE E SANCHO PANÇA COMO IMAGENS
}

\author{
Italo Oscar Riccardi León ${ }^{1}$ \\ Universidade Federal de Alfenas (UNIFAL-MG) \\ (italo.leon@unifal-mg.edu.br)
}

\begin{abstract}
Resumo: No âmbito das relações dialógicas comparativas intertextuais que permeiam as interfaces entre a literatura e o cinema, surgiu o interesse por estudar as figuras/personagens de Dom Quixote e Sancho Pança como imagens emblemáticas da obra clássica hispânica $O$ engenhoso fidalgo Dom Quixote de la Mancha de Miguel de Cervantes, publicada no século XVII, e também na versão fílmica Dom Quixote do cineasta russo Gregory Kozintsev, produzida nos anos cinquenta, tendo como finalidade principal a indagação de um olhar comparativo intertextual que as possa ressignificar ao revisitá-las enquanto leitura de imagens (PALMA, 2004; STAM, 2008 e BAULER, 2013). A proposta deste artigo discorre sobre as aproximações da literatura e do cinema enquanto configurações de linguagem artística e, logo após, objetiva examinar e conceituar a imagem como representação visual e forma portadora de pensamento (SANTAELLA 1992/1993; PAZ, 2003 e SAMAIN, 2012) para analisar, posteriormente, algumas imagens significativas de dom Quixote e Sancho Pança portadoras de um protagonismo ambivalente que cativa até hoje (NABOKOV, 2009; VARGAS LLOSA, 2010; BORGES, 2011), cujas perspectivas de análise, entre alguns dos autores abordados, enfatizam a necessidade de outro olhar contemporâneo na interpretação ou na abordagem de leitura das imagens de obras artísticas que se inserem nas proposições teóricas e dialógicas comparativas intertextuais da literatura e outras artes ou de outros sistemas semióticos.
\end{abstract}

Palavras-chave: literatura comparada, cinema, imagem, interartes, dom Quixote e Sancho Pança.

\section{LITERATURE AND CINEMA: PROPOSAL FOR A COMPARATIVE INTERTEXTUAL DIALOGUE READING OF DON QUIXOTE AND SANCHO PANÇA AS IMAGES}

\begin{abstract}
In the context of intertextual comparative dialogical relations that permeate the interfaces between literature and cinema, emerged the interest in studying the characters of Don Quixote and Sancho Panza, as emblematic images of the classic Hispanic work written by Miguel of Cervantes The ingenious gentleman Don Quixote de la Mancha, published in the seventeenth century, and also in the film version Don Quixote of the Russian filmmaker Gregory Kozintsev, produced in the fifties, with the main purpose of asking for an intertextual comparative look that might re-signify them by revisiting them while reading images (PALMA, 2004; STAM, 2008 and BAULER, 2013). This article discusses the approaches of literature and cinema as configurations of artistic language and, soon after, aims to examine and conceptualize the image as a visual representation and a bearer form of thought (SANTAELLA 1992/1993; PAZ, 2003 and SAMAIN, 2012) to analyze, afterwards, some significant images of Don Quixote and Sancho Panza who own an ambivalent role that captivates until today (NABOKOV, 2009; VARGAS LLOSA, 2010; BORGES, 2011), whose perspectives of analysis, among some of the authors approached, emphasize the need for another contemporary look at the interpretation or reading approach of images of artistic works that fit into the intertextual theoretical and dialogical comparative propositions of literature and other arts or other semiotic systems.
\end{abstract}

\footnotetext{
${ }^{1}$ Doutor em Estudos Literários pelo Programa de Pós-Graduação em Letras da Universidade Federal
} de Minas Gerais. Professor na Universidade Federal de Alfenas - UNIFAL/MG. 


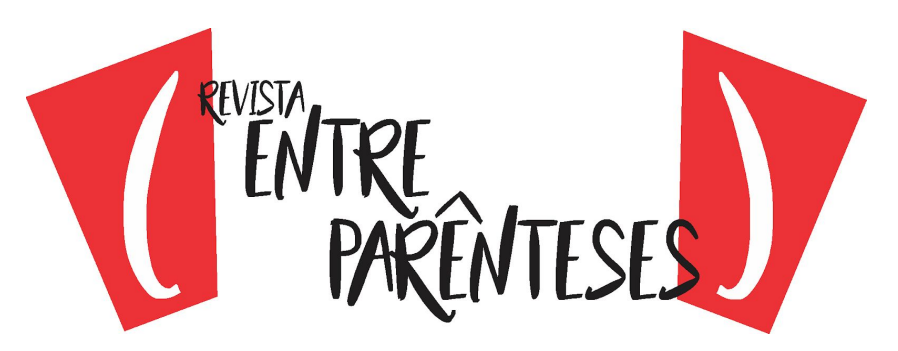

Keywords: comparative literature, cinema, image, interarts, don Quixote and Sancho Panza.

\section{LITERATURA Y CINE: PROPUESTA PARA UNA LECTURA DE DIÁLOGO INTERTEXTUAL COMPARATIVO DE DON QUIJOTE Y SANCHO PANÇA COMO IMÁGENES}

Resumen: En el contexto de las relaciones dialógicas comparativas intertextuales que traspasan las interfaces entre la literatura y el cine, surgió el interés por estudiar las figuras/personajes de Don Quijote y Sancho Panza como imágenes emblemáticas de la obra clásica hispánica El ingenioso hidalgo Don Quijote de la Mancha de Miguel de Cervantes, publicada en el siglo XVII, y también la versión fílmica Don Quijote del director de cine ruso Gregory Kozintsev, producida en los años cincuenta, teniendo como finalidad principal la indagación a través de una reflexión comparativa intertextual que les pueda atribuir un nuevo sentido al revisitarlas como lectura de imágenes (PALMA, 2004; STAM, 2008 e BAULER, 2013). La propuesta de este artículo plantea una discusión sobre las aproximaciones de la literatura y del cine consideradas como configuraciones de lenguaje artístico, y, posteriormente, objetiva examinar y conceptuar la imagen como representación visual y forma portadora de pensamiento (SANTAELLA 1992/1993; PAZ, 2003 e SAMAIN, 2012) para analizar después algunas imágenes significativas de Don Quijote y de Sancho Panza, las que son portadoras de un protagonismo ambivalente que nos cautiva hasta ahora (NABOKOV, 2009; VARGAS LLOSA, 2010; BORGES, 2011), cuyas perspectivas de análisis, entre algunos de los autores abordados, enfatizan la necesidad de otra mirada contemporánea en la interpretación o en el abordaje de la lectura de imágenes de obras artísticas que se incluyen en la proposiciones teóricas y dialógicas comparativas intertextuales de la literatura y otras artes o de otros sistemas semióticos.

Palabras clave: literatura comparada, cine, imagen, interartes, Don Quijote y Sancho Panza.

\section{INTRODUÇÃO}

No contexto aprazível e promissor de aproximações, confluências e relações comparativas intertextuais entre a literatura e o cinema, surgiu o interesse por estudar e pesquisar as emblemáticas personagens de Dom Quixote e Sancho Pança como imagens em uma das versões adaptadas da obra para o cinema, intitulada Dom Quixote (1957) do cineasta russo Gregory Kozintsev. A versão adaptada de Kozintsev foi filmada nas planícies da Criméia e teve como protagonista o ator Nikolai Tcherkassov, no papel de Dom Quixote, e de Yuri Tolubéyev, na interpretação de Sancho Pança. Na direção artística e no design da produção, assim como na caracterização das personagens, houve o assessoramento fílmico e estético do escultor Alberto Sánchez, um exilado republicano espanhol que viveu na ex-república soviética.

O engenhoso fidalgo Dom Quixote de la Mancha ou simplesmente cognominada de Quixote, obra consagrada do escritor espanhol Miguel de 


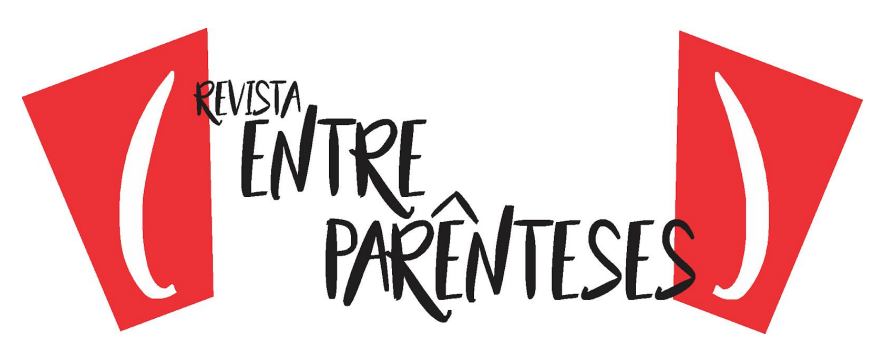

Cervantes Saavedra - publicada no início do século XVII - se delineia como sendo a primeira grande novela da modernidade que foi concebida, grosso modo, como uma paródia dos livros de cavalaria e considerada uma obra monumental que, em sua totalidade, está constituída por 126 capítulos, sendo 52 da primeira parte, publicada em 1605, e 74 da segunda parte, divulgada em 1615. Segundo Esteves (2005, p.138), trata-se de uma das obras mais traduzidas do planeta, depois da Bíblia, e, apesar das limitações em manter dados estatísticos atualizados, acredita-se que o Quixote conte hoje com cerca de 500 edições em sua língua original e mais de mil nas mais de setenta línguas a que já foi traduzido. Deste modo, transformou-se na obra mais conhecida da literatura espanhola e em uma das mais importantes da literatura universal e, assim popular, teve uma infinidade de diferentes leituras.

As personagens dom Quixote e Sancho Pança adquiriram, com o passar do tempo, uma projeção de caráter universal ocasionada pela recepção da obra cujo texto se caracteriza, principalmente, por uma narrativa engenhosa entretecida por traços paródicos, cômicos e irônicos, bem como por um enredo profuso de diálogos habilidosos e peripécias grotescas das personagens que desenrolam diversas ações que refletem, no caso de Dom Quixote, aspectos de uma loucura visível ou perceptível. Na trajetória de ambas as figuras, em função das observações da crítica exegética e visão romântica, elas também foram interpretadas como a luta constante entre a realidade e a razão, por uma parte, e a imaginação e o desejo ideal, por outra, o que provocou diferentes percepções derivadas da sua leitura.

Por sua vez, cabe destacar que, uma das consequências da diversidade como objeto de análise no olhar comparatista - abordagem de nosso interesse - foi a de que a leitura dos grandes textos da literatura deixou de ser uma única interpretação adequada, conforme esclarece Vieira (2012a, p. 69), considerando que esse tipo de investigação se inseriu no conjunto de estudos voltados para a intertextualidade que, no caso do Quixote, peculiarmente, permeia a noção de recepção compreendida em um sentido amplo e que engloba não apenas textos 


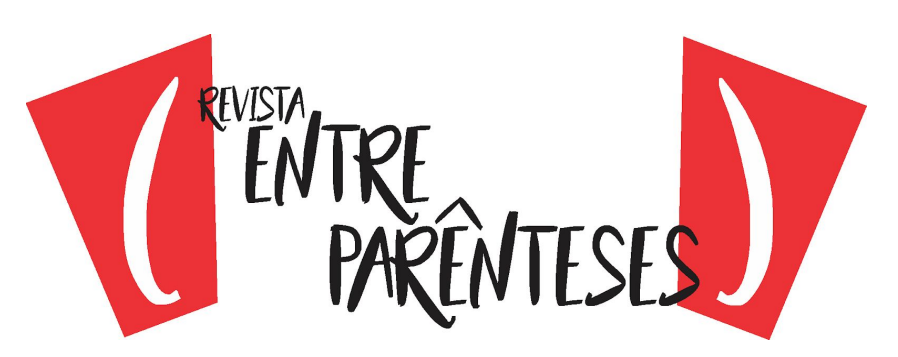

literários, mas também outras linguagens que se pautaram pela obra de Cervantes, a qual seduziu uma multiplicidade de linguagens, não apenas no âmbito literário, mas também no campo da música, pintura, escultura, cinema, artes gráficas etc., o que veio confirmar, ainda mais nossa opção pelo filme escolhido e, consequentemente, o interesse pelo estudo das relações comparativas intertextuais entre a literatura e o cinema.

É importante considerar nas linhas precedentes, a visão de recepção aludida por Vieira, na medida em que essa perspectiva abre novas possibilidades de um olhar estético para a literatura; isto é, para a leitura da obra literária, e, consequentemente, também para o universo de outras linguagens - como é o nosso caso - permitindo o estabelecimento de outros processos de interações dialógicas na recepção da obra ou texto literário. Deste modo, podemos adiantar que a leitura e interpretação ocuparão um valor de destaque na perspectiva de nossa análise.

Assim, ao se cogitar possibilidades de leitura e interpretação advindas da natureza do enfoque proposto, de caráter comparativo e intertextual voltado à literatura e outros sistemas semióticos, consideraremos a presença dos "modos de ver" ou "de ler" na medida em que o humano, como aponta Bauler (2013, p. 2013), nada observa de novo que não busque interpretar, ou seja, elaborar uma interpretação fenomenológica ou mesmo sensível para o objeto observado, aspecto relevante neste trabalho, ressaltando que, ao se produzirem leituras dialógicas entre textos literários e filmes, de acordo com Palma (2004, p.12), o conceito de leitura se amplia, redimensionando a função do sujeito-leitor, que dinamiza as formas de aquisição dos conhecimentos literários que passam a percorrer um caminho interdisciplinar.

Além do mais, ao se terem já comemorado mais de quatrocentos anos do lançamento do Quixote, e em função das incontáveis edições e reedições da obra original, versões para o teatro, o cinema, interpretações pictóricas, esculturas, charges, quadrinhos etc., há quem pense no Quixote, como enfatiza Nascimento 


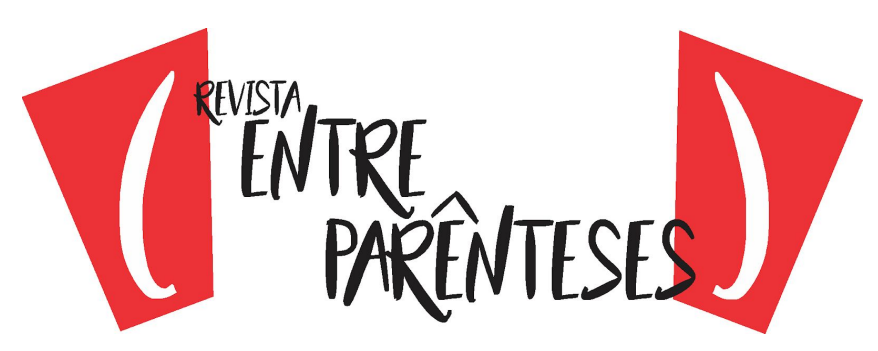

(2005, p.122), como uma obra difícil, leitura para iniciados, um mundo denso e complexo a que somente leitores privilegiados teriam acesso, sem se perceber que o Quixote - como a autora ressalta - não foi escrito para eruditos, mas para os milhões de leitores comuns que o livro tem conquistado desde que foi publicado, provavelmente leitores seduzidos pelo fascinante universo criado nas páginas de ficção traçadas pela engenhosidade cervantina.

Já a adaptação do Quixote para o cinema representa de modo evidente, uma aproximação e interação entre as linguagens literária e cinematográfica e, ao mesmo tempo, um encontro instigante e sedutor da literatura com o cinema. Do mesmo modo que na obra cervantina os protagonistas dialogam e viajam juntos enfrentando inimigos, desfazendo agravos e tentando corrigir abusos, conforme o desenrolar do enredo e a recepção do leitor, no cinema elas são recriadas de modo correlato como personagens por meio da linguagem narrativa do filme, de maneira que, ao se deslocarem pelo contexto cinematográfico delineado, dom Quixote e Sancho Pança fazem esvoaçar também a fantasia e o imaginário do leitor/receptor.

No caso da adaptação do filme de Kozintsev é pertinente destacar, a priori, que o cineasta introduziu no filme algumas modificações em relação ao enredo e à visão do texto original, conforme apontaremos mais adiante, mas sem que por isso a obra tenha perdido seu caráter referencial ou de universalidade, assim como sua correlação e similitude em relação à célebre dupla de personagens que foi projetada na tela e os outros elementos análogos, como a caracterização das mesmas, o contexto histórico, o conteúdo e o protagonismo, aspectos chaves que permitem esboçar aproximações e estabelecer relações comparativas intertextuais entre a literatura e o cinema, além do reconhecimento do filme de Kozintsev, pela crítica especializada, como sendo uma das adaptações "razoáveis" ou "plausíveis" do romance para o cinema ${ }^{2}$.

\footnotetext{
${ }^{2}$ Existem vários referenciais críticos importantes que consideram o filme de Kozintsev como uma adaptação cinematográfica "razoável" ou "plausível" da literatura para o cinema, embora tenham especificidades e formas distintas para abordá-lo, mas que se complementam (Cf. EGIDO, Los
} 


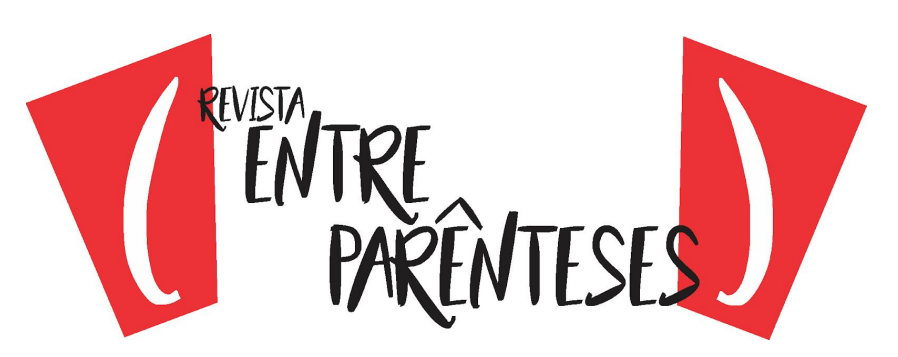

Por outro lado, embora considerar uma adaptação "razoável" ou "plausível" da literatura para o cinema possa gerar uma discussão conceitual polêmica em relação à precisão de sua leitura no sentido de discutir o que seria ou se entenderia por esse tipo de adaptação da obra literária para a tela de cinema, em nosso caso, trata-se de uma história ou enredo cujo elemento comum e estruturador das duas formas de linguagens, cujo foco são as personagens de dom Quixote e Sancho Pança como imagens, desempenham um papel chave na configuração e interpretação do sentido que é amalgamado pelo aspecto de narratividade e, ao mesmo tempo, oferece amplas condições de leitura e de interpretação, permitindo entrecruzamentos comparativos intertextuais significativos por meio das personagens que interagem no universo da ficção, em conformidade com as fronteiras da palavra escrita e a proposta da versão adaptada para o cinema que, por mais "razoável" ou "plausível" que seja, mesmo mantendo relações de fidelidade com respeito ao texto original, dificilmente ocupará o lugar da obra literária ou representará uma cópia fidedigna do texto em toda sua complexidade.

À vista disso, sustentamos que, ao comparar uma obra literária e uma versão cinematográfica, a interação gerada entre ambas as linguagens não se pode conceber no sentido de considerar que a adaptação cinematográfica seja uma espécie de "versão romanceada de um filme", como empiricamente se poderia pensar. Há pontos de contato ou interseções relevantes entre a literatura e o cinema, mas esse fato não significa que a versão cinematográfica represente uma "cópia fiel" da obra literária ou que, ao se comparar, exista um caráter de "imitação" por parte do roteiro fílmico. Portanto, exigir fidelidade de forma absoluta ou total da literatura para o cinema, ou vice-versa, seria um equívoco elementar, conforme Johnson (2004, p.42) esclarece:

A insistência na "fidelidade" - que deriva das expectativas que o espectador traz ao filme, baseadas na sua própria leitura do original é um falso problema porque ignora diferenças essenciais entre os

rostros de Don Quijote, 2004, p.137-158; STAM, A literatura através do cinema, 2008, p.65-70; e HEREDERO, Espejos entre ficciones - El cine y el Quijote, 2009, p. 201-215). 


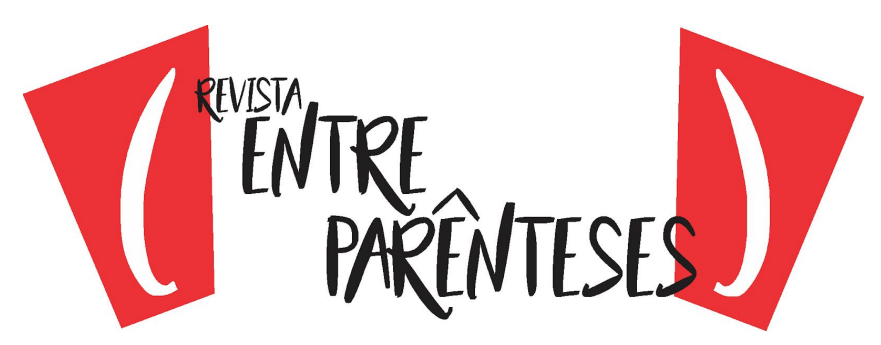

dois meios, e porque geralmente ignora a dinâmica dos campos de produção cultural nos quais os dois meios estão inseridos. Enquanto um romancista tem à sua disposição a linguagem verbal, com toda a sua riqueza metafórica e figurativa, um cineasta lida com pelo menos cinco materiais de expressão diferentes: imagens visuais, a linguagem verbal oral (diálogo, narração e letras de música), sons não verbais (ruídos e efeitos sonoros), música e a própria língua escrita (créditos, títulos e outras escritas). Todos esses materiais podem ser manipulados de diversas maneiras. A diferença básica entre os dois meios não se reduz, portanto, à diferença entre a linguagem escrita e a imagem visual, como se costuma dizer. Se o cinema tem dificuldade em fazer determinadas coisas que a literatura faz, a literatura não consegue fazer o que um filme faz.

No caso do Quixote de Kozintsev, por meio de uma adaptação apurada do seu roteiro fílmico, o cineasta condensou os episódios mais conhecidos da obra literária na tela e configurou, também, a imagem de dom Quixote como um cavaleiro andante, imbuído de ideais cavalheirescos e na companhia do seu escudeiro, assim como na obra, procurando lutar contra inimigos, enfrentar abusos e ultrajes diversos; no entanto, na versão cinematográfica, a personagem principal se envolve, por exemplo, como aspecto diferenciador da versão fílmica, em confrontos de classes sociais e demonstra que sabe confraternizar com camponeses e desfavorecidos, sendo mesmo capaz de se misturar com eles na roça e manter contato também com a natureza.

O foco de nosso estudo está centrado na leitura e interpretação das personagens de dom Quixote de la Mancha e Sancho Pança concebidas como imagens advindas do texto cervantino, o Quixote - primeira e segunda parte -, e uma das suas versões adaptadas ao cinema, o filme de Kozintsev. Contudo, esclarecemos que o objetivo principal do trabalho é propor um possível novo olhar ou outra leitura que possa ressignificar essas renomadas personagens enquanto imagens ao revisitar o texto clássico e uma de suas versões cinematográficas.

\section{UMA APROXIMAÇÃO AO ESTUDO DA IMAGEM}




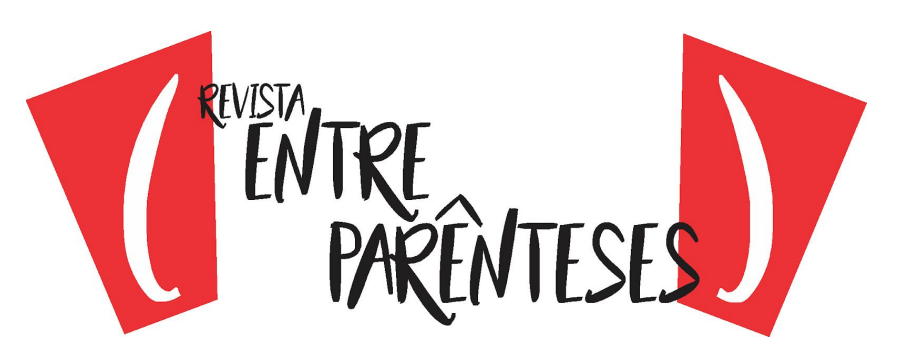

Certamente as imagens constituem uma forma complexa de linguagem e de manifestação expressiva que envolve intrincados processos e mecanismos perceptivos, abrangendo uma diversidade de formas de representação incluindo desde a percepção sonora até outras experiências sensíveis. É importante acrescentar que existem imagens de várias espécies e que elas se dirigem aos nossos diversos sentidos, assim como apontam Aumont e Marie (2006, p.160), autores que discriminam imagens visuais, auditivas, táteis, olfativas etc., ou seja, imagens que correspondem a certa sensação acompanhada de ideias e foram denominadas de "imagens mentais". Por conseguinte, a imagem pode ser produzida por um fenômeno natural-reflexo, sombra, visão através de um corpo transparente e, também, por um gesto humano intencional. Desta maneira, se poderia ler ou interpretar a imagem como sendo um estímulo sensorial provocado pelo mundo sensível.

Por sua vez, Santaella (1992/1993, p.37) assinala que há inúmeras "coisas" que podem ser chamadas de imagem, cuja vasta relação inclui desde figuras, diagramas, fotos, hologramas, ilusões óticas, sombras até mesmo poemas, memórias, estátuas, manchas e inclusive ideias, entre outras. Ela destaca que as imagens perceptivas atraíram sobremaneira os estudiosos nas mais variadas áreas do conhecimento, da filosofia à ótica, da literatura à neurologia; em seguida, cogita que foi dos caracteres extraídos das imagens perceptivas que todos os outros tipos de imagens começaram a ser descritos.

A imagem pode ser compreendida como representação visual e/ou mental. Paz (2012, p.37-38) a define como "figura real ou irreal que evocamos ou produzimos com a imaginação" e "cifra da condição humana." Para esse autor, as imagens "são produtos imaginários", e ele enfatiza que com a palavra "imagem" se pode designar ainda toda forma verbal, frase ou conjunto de frases que foram classificadas pela retórica e passaram a se chamar de comparações, símiles, metáforas, jogos de palavras, paronomásias, símbolos, alegorias, mitos, fábulas. 


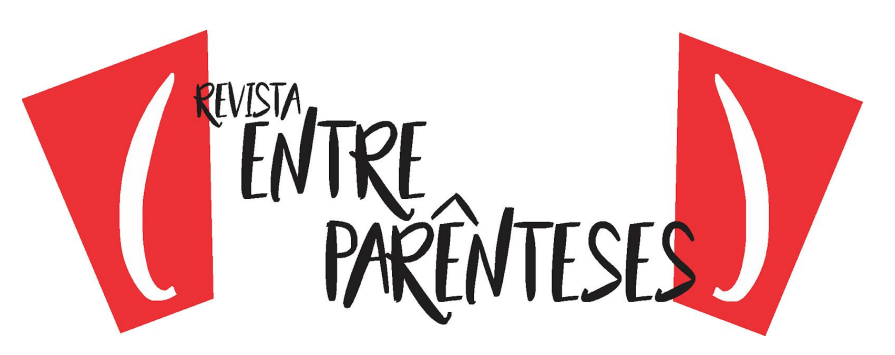

Assim, conforme a escolha da linguagem, a imagem se faz presente por meio das palavras na literatura e de forma visual multimodal no cinema, ou seja, em ambas as linguagens, e até com o predomínio de uma sobre a outra, a imagem surge conforme as intencionalidades estéticas a serem escolhidas ou elaboradas.

Ao interagir no âmbito dessas linguagens portadoras de imagens e dos seus vários sentidos, seja pela palavra literária e/ou pela imagem cinematográfica, cada leitor ou espectador terá um modo de percebê-las de acordo com o impacto que a imagem produza na sua percepção experiencial e na sua mente. De acordo com Cardoso (2003, p.67), a "alquimia da imagem" foi capaz de atrair o próprio texto literário, levando o romance a dois tipos de reação: a aproximação da letra à imagem, quando a narrativa reflete a visão da câmara cinematográfica, e o distanciamento da letra face à imagem, quando, por exemplo, o romance valoriza o monólogo interior e impede a tradução pela imagem do fluxo de consciência da personagem. Assim, letras e imagem se inter-relacionam e encontram-se muitas vezes distantes ou unidas, principalmente pela relevância histórica, social e cultural que possuem, bem como pelas capacidades de representação ideológica. Enfim, a imagem tem estado presente tanto na literatura como no cinema, e também tem sido objeto de estudo de outras áreas como a filosofia, história, antropologia, semiótica, fotografia, arte, estética, educação, psicologia, comunicação, publicidade etc.

$\mathrm{Na}$ procura dessa nova proposta de leitura e de um referencial teórico-crítico válido que permitisse abordar as personagens de dom Quixote e Sancho Pança apercebidas como imagens na literatura e no cinema, deparamos de forma encorajadora com um referencial contemporâneo que nos possibilita abordar as personagens de dom Quixote e Sancho Pança concebidas como imagens no âmbito das interações entre a literatura e outras artes. Em alguma medida, as reflexões da abordagem pretendida, possibilitam delinear a proposta de uma leitura dialógica intertextual comparativa provocada na apreensão e tensão do fenômeno 


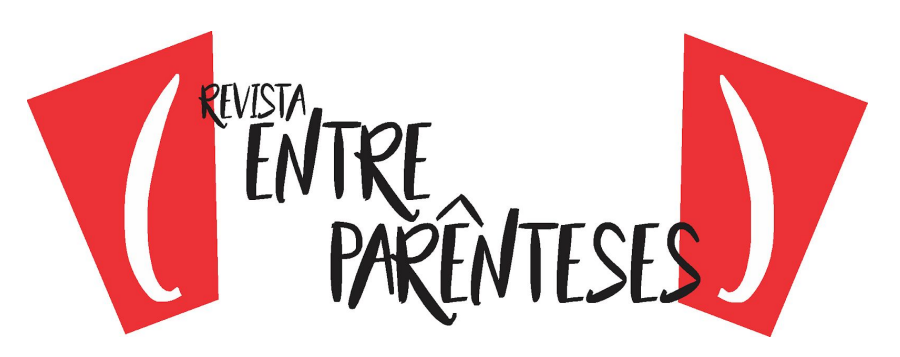

estético que se pode aplicar ao estudo das personagens de dom Quixote e Sancho Pança como imagens.

Na relação da literatura e o cinema e/ou outras artes, há necessidade de outro tipo de olhar discursivo ou postura na interpretação das imagens das obras artísticas permitindo redimensionar o "ato de ver"; isto é, de outras possibilidades do olhar estético contemporâneo, sendo pertinente considerar o que de forma acertada Rojo (2012, p.100) assinala quando esclarece que os processos de análise e processamento das imagens estão em um terreno de deslocamento determinado pelo espaço, tempo e estruturas simbólicas, bem como pela capacidade imaginativa de enunciadores e receptores específicos de cada obra em questão.

Ao se aproximar do estudo da imagem, a partir de uma perspectiva dialógica intertextual comparativa, busca-se compreendê-la e desvendar os seus mecanismos, assim como de indagar afinidades ou estabelecer, simplesmente, pontos de contato, convergências ou articulações factíveis, dadas as possibilidades sensíveis e/ou polivalentes que a natureza da imagem carrega consigo, de forma coexistente, com sua capacidade extraordinária para sugerir ou de evocar significados e interpretações que podem ir muito além da sua projeção, desejo, propósito, gosto e/ou criação de quem a produziu.

Assim, pensar a imagem hoje nos leva a percorrer um pensamento dialético que se articula e debruça de forma inequívoca conectada com o conhecimento do mundo perceptível, do fenômeno estético, do imaginário, da memória, da intuição perceptiva das formas, mobilidade do olhar do leitor/receptor/espectador, enfim, do recôndito sensível do humano. Deste modo, é possível conjecturar, de acordo com Samain (2012, p.14), que "as imagens são portadoras de pensamento e como tal nos fazem pensar" e ainda, ao se associarem, de considerá-las como "formas que pensam".

Sem pretender abordar outros aspectos fenomenológicos, heurísticos e/ou dimensões epistemológicas que a imagem sugere no seu estudo - por não 


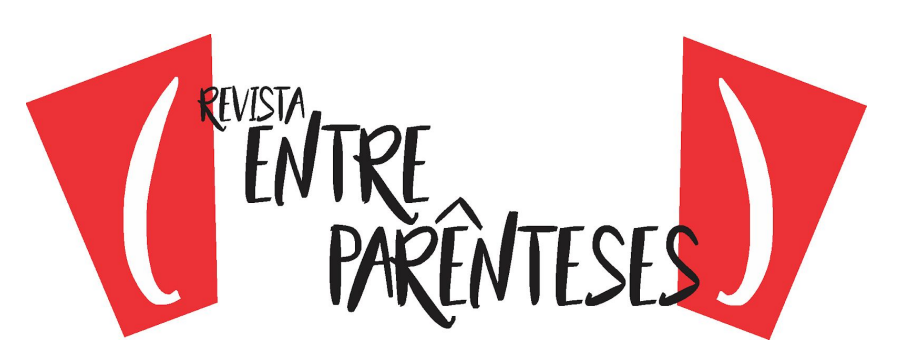

constituir uma finalidade especifica deste trabalho -, torna-se relevante considerar que as imagens, ao se tornarem independentes em relação ao objeto que representam, além de abrigar uma história própria, adquirem uma vida autônoma, permitindo que possam ser vistas como "objetos" inseridos no universo próprio das imagens, ou seja, ao se transformar em "coisas palpáveis", as imagens obtiveram a capacidade de serem analisadas como "objetos autônomos", apesar de ainda continuar remetendo a outros objetos e também de substituí-os.

Desta maneira, ao evocar imagens em torno das personagens de dom Quixote e Sancho Pança, surge uma profusão de outras imagens das personagens no horizonte do espaço histórico e sociocultural que extrapolam os limites da obra cervantina chegando, inclusive, até engrandecê-la ainda mais. Elas adquirem outras formas e formatos que se espalham pelas inúmeras e magníficas reproduções iconográficas e coleções que envolvem as personagens de dom Quixote e Sancho Pança. De acordo com Millán (2004, p.138), depois de publicada a primeira parte do Quixote, pouco tempo depois, e ainda em 1605, surgiu uma edição elaborada em Lisboa que foi impressa com uma gravura que representava um cavaleiro e seu escudeiro. Para o autor, essa representação seria o que deu início, posteriormente, à longa tradição das inumeráveis gravuras que enriqueceram as outras elaboradas com as distintas edições da obra, fator que incidiu e forjou o cânone da imagem ou recriação iconográfica constante da célebre dupla.

$\mathrm{Na}$ atualidade, constata-se que há uma incalculável proliferação de imagens advindas de outras linguagens ou de outros meios de divulgação como capas de livros, revistas, coleções de arte, jornais, cartazes, gibis, histórias em quadrinhos, livros ilustrados etc. De igual modo, é oportuno destacar que pela Internet se podem acessar alguns bancos iconográficos especializados sobre 0 Quixote, como o Quijote Banco de Imágenes - QBI, organizado pelo Prof. José Manuel Lucía Megías, coordenador do Centro de Estudios Cervantinos de Alcalá de Henares; o banco Iconografía del Quijote, desenvolvido pela Universidade do Texas, 


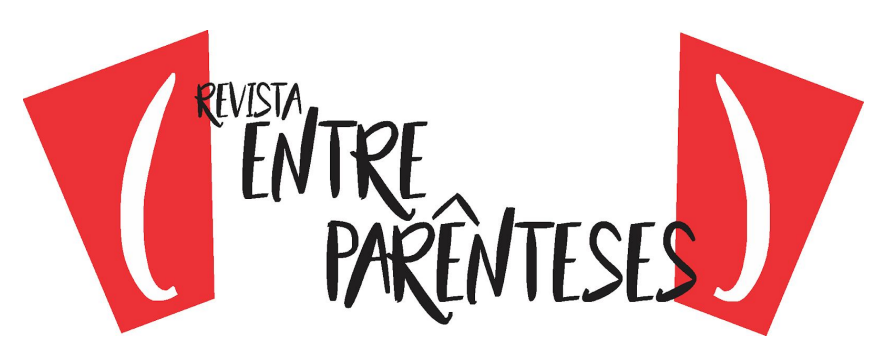

USA, dirigido pelo Prof. Eduardo Urbina e também o Museo Iconográfico del Quijote localizado na cidade de Guanajuato, México.

Ao estudarmos as personagens de dom Quixote e Sancho Pança como imagens na obra e no filme escolhido - foco central desta abordagem - se deve ter presente que, apesar das distinções, tendências ou perspectivas que sua abordagem induz ou insinua, as memoráveis figuras possuem uma capacidade inerente de superar quaisquer rótulos e de se amoldar às várias possibilidades de recepção e interpretação, o que tem demonstrado sua singular versatilidade, maleabilidade e vigência desde a irrupção criativa de sua presença na sociedade até o tempo presente. Vieira (2012b, p. 25-26) destaca que o traço exemplar da obra - e que, por extensão, se pode aplicar perfeitamente às personagens em questão radica na sua predisposição de se adequar às diversas tendências e de ser permeável às mais diversas culturas e às mais variadas interpretações capazes de aliar, inseparavelmente, arte e pensamento, um aspecto bastante significativo no escopo deste trabalho, porque nos permite estudar e incursionar, de forma dialógica intertextual comparativa ou interartes ${ }^{3}$, pelo universo das personagens em destaque apercebidas como imagens.

Desta maneira, tanto a literatura como as adaptações cinematográficas proporcionam imagens de uma história ou de um enredo que pode fazer parte tanto da literatura como do cinema, assim como um argumento advindo da literatura pode ser adaptado ou roteirizado para o cinema. Por conseguinte, contemplar ou indagar uma imagem implica um ato perceptível e sensível que se abre ao imaginário,

\footnotetext{
${ }^{3} \mathrm{Na}$ visão do pesquisador Clüber "enquanto a Literatura permanecer como o ponto de referência dominante, há boas razões para considerar o Comparativismo como o espaço adequado para os Estudos Interartes"; além do mais, sua apreciação se apoia - como ele mesmo observa - pelo predomínio atual da arte da palavra sobre as outras artes nesse campo de estudo atestado por centenas de publicações a cada ano, e ainda esclarece: "há décadas, na condição de comparativista, tenho trabalhado com a 'comparação' da Literatura com algo que, embora seja de outra ordem em relação à Literatura, possa ser submetido, juntamente com esta, a um conceito geral que costumamos chamar de 'arte'. Minha área de interesse foi denominada nos EUA, por muito tempo, 'Artes Comparadas', termo compreensível apenas para aqueles que o associavam a 'Literatura Comparada'. Hoje em dia, a área em que atuo recebe, em inglês, o nome de 'Interarts Studies', que corresponde a 'Estudos Interartes', em português [...]' (CLÜBER, 2006, p.11-13).
} 


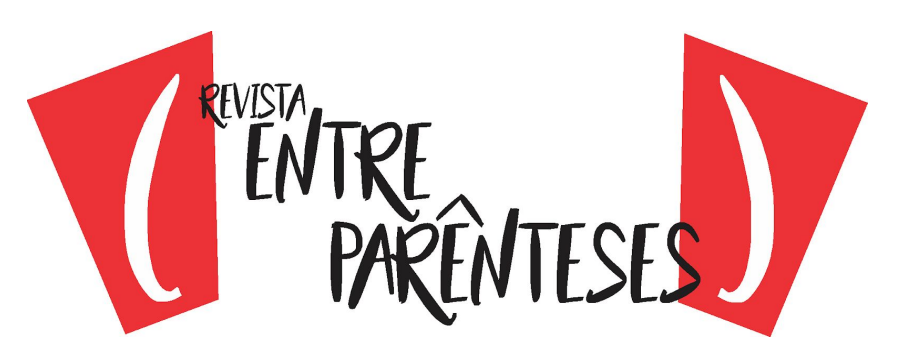

permitindo uma abertura para outras possibilidades de leitura que não reproduzem o real porque o real se pode, também, compreender como um paradoxo complexo que não se deixa reproduzir. Assim, pensar acerca das personagens de dom Quixote e Sancho Pança como imagens significará deparar-se com rastros imagéticos desafiadores que se encontram espalhados como se fossem os "enigmas" de uma espécie de "caça ao tesouro" ou de um "jogo engenhoso", imaginativo e ludíbrio que precisa ainda ser "desentesourado" para ser compreendido e ressignificado.

\section{A IMAGEM EM DOM QUIXOTE DE LA MANCHA}

As personagens de dom Quixote e Sancho Pança podem-se observar, a priori, como imagens de um clássico literário que atiça nossa curiosidade, desperta nosso interesse e está vigente na contemporaneidade porque possui a capacidade de se atualizar constantemente; o que nos faz considerar, aqui, uma das premissas sobre os clássicos, proposta por Calvino (2007, p.12), para quem esses livros, "quanto mais pensamos conhecer por ouvir dizer, quando lidos de fato mais se revelam novos, inesperados, inéditos."

Os estudos sobre o Quixote, de acordo com Vieira (2012b, p. 23), tiveram o mesmo destino das pesquisas voltadas para as obras clássicas, que apontam para um sinal de conflito entre duas tendências: por um lado, a abordagem da obra a partir dos pressupostos que orientaram sua criação, com o intuito de resgatar os domínios possíveis da escritura e da leitura tendo em conta os leitores contemporâneos; por outro, a abordagem que se empenha em adequar o sentido aos referenciais próprios do leitor moderno, buscando seus possíveis significados a partir do que eventualmente o texto é capaz de dizer para o público de hoje.

Ao evocarmos as personagens de dom Quixote e Sancho como imagens, ambas se percebem como figurações significativas que, embora nem todos os leitores se lembrem de quem foi Cervantes, conforme assinala Krause (2007, p. 15), certamente todos os que são leitores reconhecem o nome de dom Quixote e o 


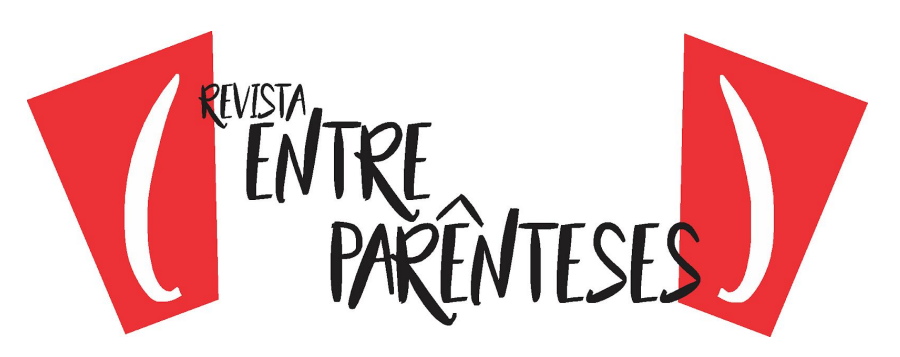

associam imediatamente ao amigo Sancho Pança; logo depois se lembrarão de que o principal romance de Cervantes foi considerado o melhor romance de todos os tempos. Entretanto, se se pergunta a esses leitores se o leram, muitos até dirão que o fizeram na escola, sem atentar que tiveram em mãos apenas uma adaptação de clássicos para jovens; mas, se a pergunta ainda se refina mais, fazendo-se referência àquele romance de dois volumes e cerca de mil páginas, a resposta será provavelmente uma constrangida negativa.

No desenvolvimento do enredo narrativo percebemos que, à medida que ambas as personagens, tanto dom Quixote de la Mancha, o cavaleiro andante, como Sancho Pança, seu adepto escudeiro, se desenvolvem e evoluem enquanto parceiros protagonistas que, ao entrelaçar e compartilhar suas vidas, ora divergindo ora se complementando, comovem e atraem pela doideira criativa de suas aventuras, dinâmica dos seus paradoxos, paramento das suas feições e personalidades, até descobrir que, pela convivência e intimidade de suas jornadas, elas são figurações de "carne e osso" e possuem as mesmas ambiguidades e contradições dos seres humanos; isto é, daquilo que é viver e sonhar, trafegando pela vida e fazendo referência, iniludivelmente, às dimensões da realidade e da consciência, mas também da ficcionalidade e da idealização.

Ao se referir à ilustre dupla e ao texto cervantino, Bezerra (2005, p. 100) diz que se trata da história do fidalgo Alonso Quijano, que, de tanto ler livros de cavalaria, tresleu e passou a ver o mundo pelos olhos da literatura, tentando levar a vida como se estivesse vivendo o enredo de um romance de cavalaria, "razão" que permite ao fidalgo tornar-se um cavaleiro andante.

$\mathrm{Na}$ procura de outros rastros perceptivos ou indícios descritivos das personagens de dom Quixote e Sancho Pança, por constituírem imagens figurativas significativas dos protagonistas, deparamos, entre uma diversidade de possibilidades existentes, com a importante menção feita por Vargas Llosa (2004, p. XIII), por ocasião da celebração da edição do IV Centenário do Quixote. Na sua 


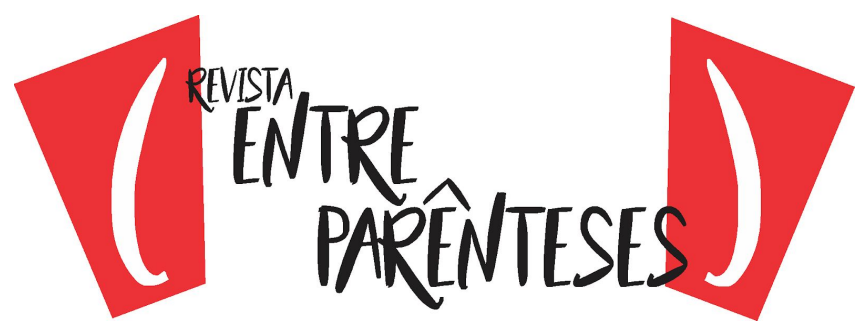

abordagem introdutória, Llosa considera literalmente "uma imagem" a obra imortal de Cervantes; em seguida, faz alusão à personagem principal (dom Quixote), descrevendo-a como:

a de um fidalgo cinquentão, embutido numa armadura anacrônica e tão esquelético como seu cavalo, que, acompanhado por um camponês tosco e gordalhão montado num jumento, que faz as vezes de escudeiro, percorre as planícies de La Mancha, geladas no inverno e quentes no verão, em busca de aventuras. $O$ anima um desígnio enlouquecido: ressuscitar o tempo eclipsado séculos atrás (e que, aliás, jamais existiu) dos cavaleiros andantes que percorriam o mundo socorrendo aos desvalidos, desfazendo agravos e fazendo reinar uma justiça para os seres do comum e que de outro jeito estes jamais atingiriam, daquele que se impregnou lendo livros de cavalarias, às que ele atribui a veracidade de escrupulosos livros de histórias. Este ideal é impossível de atingir porque tudo na realidade na qual vive o Quixote o desmente: já não há cavaleiros andantes, já ninguém professa as ideias nem respeita os valores que movimentavam aqueles, nem a guerra é já um assunto de desafios individuais nos quais, seguindo um meticuloso ritual, dois cavalheiros confrontam forças. (VARGAS LLOSA, 2004, p. XIII)

O retrato feito por Vargas Llosa aponta, evidentemente, para dom Quixote, protagonista cuja imagem tem sido uma das mais difundidas e conhecidas do texto cervantino ao longo já de mais quatro séculos. Uma imagem emblemática presente desde o início da obra e que se avista como aquele fidalgo cinquentão apelidado de "Quijada" ou "Quesada", que em suas horas vagas começou a ler livros de cavalaria com tal dedicação e afeição que, segundo o autor da obra, além de esquecer as atividades para com a caça e as obrigações administrativas da sua fazenda, ficou dias e noites fisgado na sua leitura: "e assim, do pouco dormir e muito ler se the secaram os miolos, de modo que veio a perder o juízo." (CERVANTES, 2012b, p. 70). Depois ele veste uma armadura velha e empunha algumas armas, transmuda seu rocim em Rocinante, deixa o povoado onde mora e sai cavalgando

\footnotetext{
${ }^{4} \mathrm{Na}$ versão da obra traduzida que estamos empregando, se assinala que "Quijada" ou "Quesada" se podem considerar como substantivos comuns, dado que seriam nomes que significam "queixada" (mandíbula) e "queijada" (torta de queijo), respectivamente (CERVANTES, 2012b, p.68).
} 


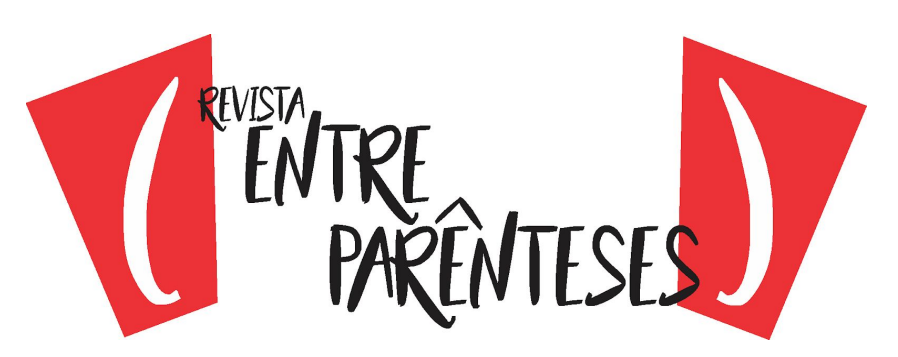

em busca de aventuras; primeiro sozinho, e depois com Sancho Pança, que se converterá em seu devotado escudeiro.

Não resta dúvida de que o fidalgo perdeu a razão porque teve a ideia tresloucada de se transformar em um cavaleiro andante que, após lembrar-se da tradição dos seus antecessores, intitulou-se de dom Quixote de la Mancha, nome que, segundo a opinião do próprio fidalgo, e também do seu autor, "declarava bem vivamente a sua linhagem e pátria, e a honrava tomando-a por epíteto." (CERVANTES, 2012b, p. 74). A postura do cavaleiro manifesta um acentuado e evidente caráter transgressor que bem se poderia considerar uma espécie de "feitiço da ficção", isto é, dom Quixote experimenta em sua própria pele os efeitos da irrealidade das imagens que povoam sua cabeça, advindas do tipo de leitura feita com total dedicação e intensidade, assim como revelado pelo próprio narrador da obra:

Encheu-se-Ihe a fantasia de tudo aquilo que lia nos livros, tanto de encantamentos como de contendas, batalhas, desafios, ferimentos, galantarias, amores, borrascas e disparates impossíveis; e se lhe assentou de tal maneira na imaginação que era verdade toda aquela máquina daquelas soadas sonhadas invenções que lia, que para ele não havia no mundo história mais certa. (CERVANTES, 2012b, p. 71)

Outra imagem sugestiva é aquela descrita e sustentada por Nabokov, a qual se origina na ideia do endoidecimento ou perda do juízo do fidalgo manchego Alonso Quijano. Nabokov considera dom Quixote "um lúcido louco, ou como um louco no limite da cordura; um louco dentro dos justos limites, uma mente às escuras com interstícios de lucidez" (NABOKOV, 2009, p. 43-44, tradução nossa). Essa visão cria uma percepção ambivalente sobre o protagonista configurando, as faces de uma mesma unidade identitária. Para Nabokov, a realidade e a ilusão se encontram entretecidas na trama da vida; em seguida, para validar sua observação, alude a uma passagem do texto cervantino em que Dom Quixote chama a atenção de Sancho dizendo:

- Olha Sancho, pelo mesmo que antes juraste eu te juro - disse D.

Quixote - que tens o mais curto entendimento que tem nem teve 


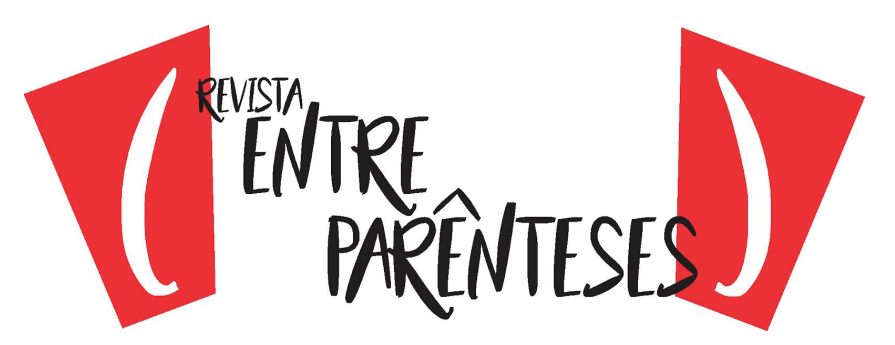

escudeiro no mundo. Será possível que neste tempo que andas comigo não tenhas percebido que todas as coisas dos cavaleiros andantes parecem quimeras, necedades e desatinos, e que são todas feitas às avessas? E não porque seja isto assim, mas porque sempre anda entre nós uma caterva de encantadores que todas as nossas coisas mudam e trocam, e as tornam segundo seu prazer e segundo a vontade que têm de nos favorecer ou destruir; e assim, isto que a ti parece bacia de barbeiro a mim parece o elmo de Mambrino e a outro parecerá outra coisa.(CERVANTES, 2012b, p. 332)

$\mathrm{Na}$ passagem referida, dom Quixote lamenta que ainda seu escudeiro não tenha reconhecido que as artes dos cavaleiros andantes, embora pareçam quimeras, tolices ou desatinos, sejam, ao contrário, realidades; assim, O elmo de Mambrino $^{5}$ seria a mesma coisa que uma bacia de barbeiro; portanto, uma mesma coisa parece equivalente à outra. Por conseguinte, a imagem da loucura de dom Quixote não estaria só conformada por traços patéticos, mas sim corajosos: a personagem leva a sério suas verdades e abdica de julgar a verdade dos demais. Deste modo, a fantasia quixotesca não se afastaria do verdadeiro conhecimento, mas, contrariamente, ela seria a via para esse conhecimento.

Contudo, não é discordante associar a imagem indissolúvel de Sancho Pança, escudeiro, montado em um jerico ou burrico, junto à de dom Quixote, seu amo e cavaleiro andante, ambos percorrendo as trilhas manchegas. Sancho Pança é um camponês simples, de baixa estatura, barriga volumosa, chefe de família e socialmente inferior a dom Quixote. Esse retrato faz Nabokov concebê-lo como "imagem de dignidade néscia e idade madura"( 2009, p. 46, tradução nossa), e

\footnotetext{
${ }^{5} \mathrm{O}$ elmo de Mambrino faz referência a um suposto capacete de ouro de propriedade do lendário rei moro Mambrino, muito almejado pelos cavalheiros de Carlos Magno na época do Império Carolíngio. $\mathrm{O}$ elmo era ambicionado pelos guerreiros em virtude de se acreditar que sua posse os tornaria invulneráveis. No Quixote, o episódio do elmo de Mambrino está narrado no Capítulo XXI da primeira parte da obra. Dom Quixote e Sancho Pança avistam um homem a cavalo. Por estar chovendo, este leva algo reluzente na cabeça. Imediatamente dom Quixote julga se tratar do afamado elmo e arremete contra o homem, um simples barbeiro. O homem foge assustado deixando cair de sua cabeça a bacia. Sancho ri do seu senhor quando dom Quixote coloca a bacia na sua cabeça com a certeza de que se tratava do insigne elmo. No entanto, o suposto elmo de Mambrino era, de fato, uma rudimentar bacia dourada de barbeiro.
} 


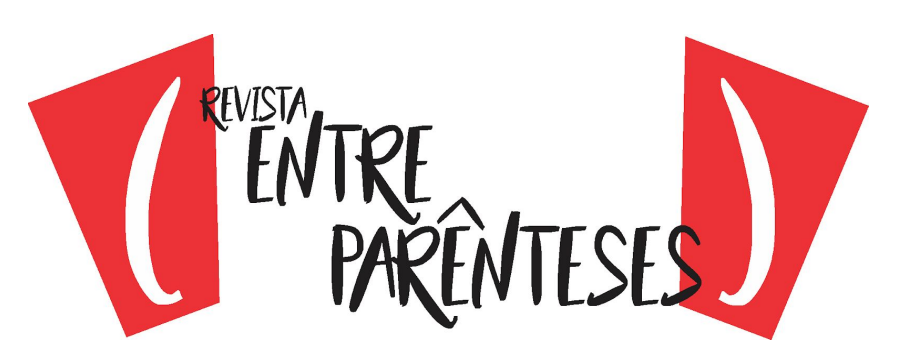

capaz de considerar que, convivendo com dom Quixote, sua imagem e sua mente se poderão esclarecer, aspectos que, de fato, acontecerão ao longo do desenvolvimento dos traços da personalidade de Sancho Pança em razão das influências e relações estreitas de amizade e companheirismo entre as duas personagens. Nabokov nos convida, imaginando - e, diríamos até de forma quase cinematográfica - a que contemplemos dom Quixote e seu escudeiro como duas silhuetas pequenas que vão caminhando, lá longe, sobre um fundo de crepúsculo dilatado e aceso, cujas sombras negras, enormes, e uma delas especialmente magra, se estendem sobre o campo aberto dos séculos e chegam até nós. Por sua vez, Sancho Pança será redimido de sua serventia, do trabalho e da pobreza, conforme observa Díez (2004, p.175), graças à fantasia do cavaleiro que, como um ímã, o atrairá ao polo da ficção. O camponês analfabeto vive uma experiência livresca e, ele mesmo, se converterá em palavra no texto de um sonho que jamais poderá ler escrito com a pena de sua fantasia.

No âmbito das relações interliterárias de leitura e interpretação, desabrocha, também, outra imagem perceptível do cavaleiro andante: trata-se da visão peculiar de Borges (2011, p.131), para quem dom Quixote pode ser considerado "um amigo", alguém que, segundo ele, "sempre há prazer" e "uma sorte de felicidade" que "não acontece com todos os personagens de ficção". Ao se referir à obra cervantina, Borges a enxerga como um conflito entre os sonhos e a realidade, porém esclarece que essa afirmação está errônea porque não há causa para que consideremos que um sonho seja menos real que o conteúdo do jornal de hoje (2011, p.132, tradução nossa). Imbuídos por uma óptica borgeana podemos, consequentemente, contemplar a realidade transcendendo o universo físico ou natural e ressignificar, a percepção do visível, de forma que um determinado acontecimento factual ou algo extraordinário, fora do comum ou sobrenatural, estabeleça uma nova ordem de apreensão, partindo da configuração dessa mesma realidade. 


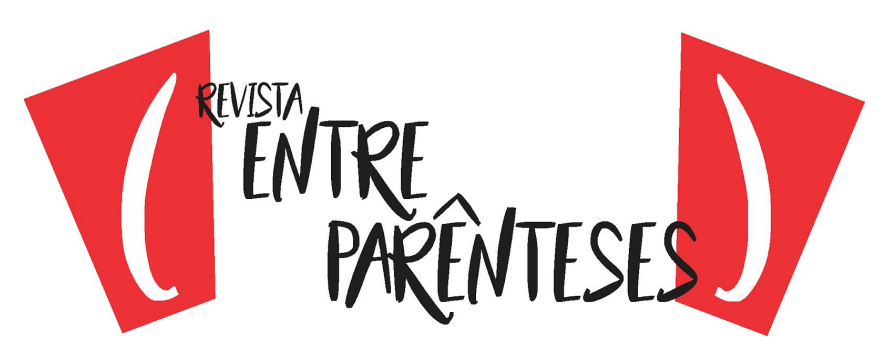

Por conseguinte, apesar de serem diferentes e opostos - até contraditórios -, dom Quixote e Sancho Pança se tornaram bons amigos pela convivência mantida ao longo da obra, permeada por um sentimento sincero de amizade e cordialidade, vale dizer, de amor. Isso evidencia o surgimento de uma imagem afável e empática que se integraliza e socializa por meio das aventuras e experiências que ambos têm oportunidade de compartilhar com singular afeição.

Apesar de apresentar traços distintos em sua maneira de se comportar e enxergar a vida em relação a dom Quixote, a fidelidade de Sancho Pança se evidencia ao defender e acompanhar seu amo, com lealdade extrema, em suas aventuras e façanhas. Se a ideação imaginária de um universo fantasioso pulsa na mente do cavaleiro andante e o faz encarar e esbarrar com uma realidade enfadonha, o escudeiro Sancho Pança, por sua vez, na sua simplicidade prosaica, sabe lidar como ninguém com a vida cotidiana e suas ambições materiais, aferrado à terra e, por vezes, até de forma surpreendente, revelando observações sagazes, como na aventura noturna em que dom Quixote arremete contra uns encamisados com tochas acesas que carregavam um corpo morto e Sancho Pança, olhando fixamente para dom Quixote, à luz de uma tocha, enxerga nele uma imagem sintomática e inusitada que o faz apelida-lo de "o Cavaleiro de Triste Figura", cognome de que dom Quixote gostou bastante e que considerou muito propício a sua condição, adotando-o imediatamente ${ }^{6}$.

Ao refletir a respeito das personagens em foco, compreendidas como imagens, se tem a impressão de que estivéssemos mergulhando, por momentos, no interior de uma "estrutura de caixa chinesa", conforme assinala Vargas Llosa (2004, p. XXIV). A comparação é possível se pensarmos na condição de dubiedade e de assombro a respeito da história que os leitores lerão e que estará contida dentro de outra, anterior e mais ampla, a qual só poderemos adivinhar de forma análoga ou,

\footnotetext{
${ }^{6}$ Essa passagem pode ser apreciada na versão de referência da obra em português, Parte I, Capítulo XIX (CERVANTES, op. cit., 2012, p. 252-253).
} 


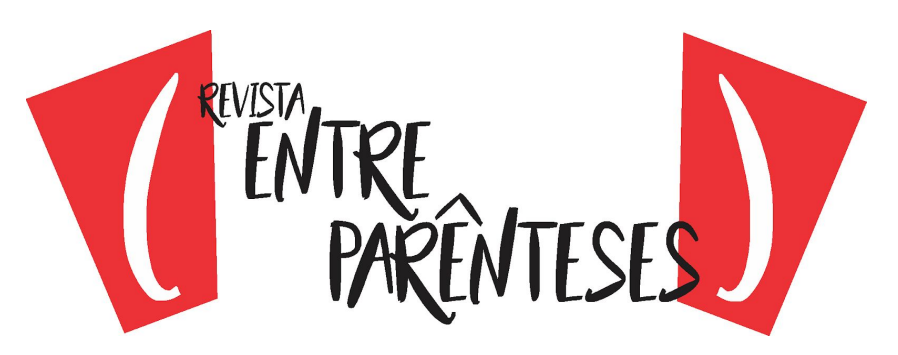

talvez, ao estarmos frente ao mistério ou enigma de uma matryoshka ${ }^{7}$, o que conformaria reflexos de uma espécie de "jogo de espelhos" a projetar imagens ou visões da realidade e da imaginação, mas que deve contracenar, também, com a rigidez de um código severo e austero a que o cavaleiro andante deve obedecer, exigindo-lhe uma adesão incondicional.

Assim, temos a impressão de que as personagens dom Quixote e Sancho Pança, enquanto figurações imagéticas surgem de uma obra polimorfa e multifacetada que é capaz de sugerir sempre novas ideias aos seus leitores, porque carrega no seu íntimo uma espécie de "seguro de sobrevivência". Uma obra cambiante que, provavelmente, nunca se acabe por conhecer, já que seus insignes personagens possuem a capacidade de projetar imagens que se vão ajustando aos sonhos de cada geração de leitores.

\section{A IMAGEM EM O FILME DOM QUIXOTE}

Dom Quixote e Sancho Pança constituem personagens clássicas que estão entre as mais famosas da literatura universal. O impacto dessa distinção originou diferentes imagens que foram reproduzidas ao longo do tempo, compondo uma considerável e variada iconografia ${ }^{8}$ sob a forma de desenhos, xilogravuras, esculturas, estampas, ilustrações e pinturas exemplares. As notáveis personagens inspiraram artistas destacados, entre os quais se podem citar, por exemplo, William Hogarth, Honoré Daumier, Gustave Doré, Francisco Goya, Pablo Picasso, Salvador Dalí, Vasco Prado e Cândido Portinari.

\footnotetext{
${ }^{7}$ Nome que identifica uma boneca russa construída por um conjunto de bonecas que se colocam umas dentro das outras.

${ }^{8}$ Há diversos estudos que têm abordado o aspecto iconoclasta ou gráfico das ilustrações que foram reproduzidas ao longo do tempo sobre dom Quixote e Sancho Pança e que originaram perspectivas teóricas interessantes (Cf. LUCÍA MEGÍAS, Leer el Quijote en imágenes. Hacia una teoría de los modelos iconográficos, 2006, e também Cf. FLORES, Da palavra ao traço: Dom Quixote, Sancho Pança e Dulcinéia del Toboso. 2007. Tese).
} 


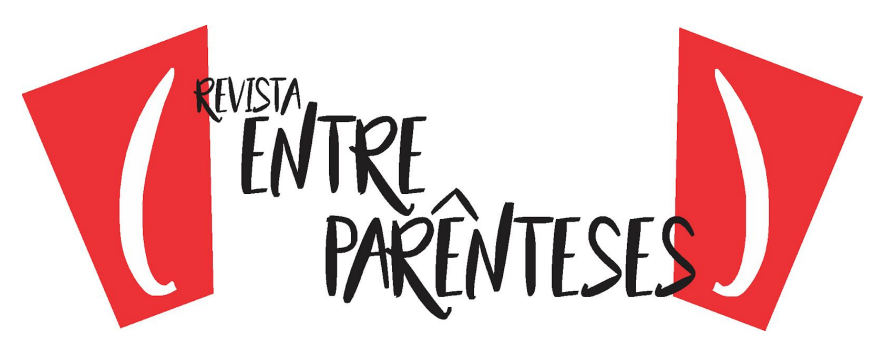

A partir da socialização do cinema como um bem cultural e como espetáculo, o Quixote despertou um forte interesse de adaptação à tela, o que permitiu que o cavaleiro andante e seu leal escudeiro assumissem diferentes feições figurativas no cinema, suscitando um fenômeno sui generis denominado "filmografia quixotesca"9. O elenco de atores que têm representado Dom Quixote e Sancho Pança no cinema é vasto, assim como sua presença em outros gêneros cinematográficos, envolvendo curtas-metragens, filmes de animação, desenhos animados e documentais diversos, além das variadas encenações para o teatro, o balé e a criação de musicais. Pode-se constatar que surgiram diversos esforços e iniciativas de investigação para levantar e catalogar toda a imensa produção das versões adaptadas do Quixote para o cinema e para a televisão.

Ao adaptar uma obra literária para o cinema, a transposição representa um processo complexo e desafiador cujos resultados revelam, particularmente no caso do Quixote, ousadas aproximações ao texto cervantino, que podemos considerar como "condensações" ou "sínteses" da obra fonte. Elas foram concebidas sob a égide dos interesses despertados pelo olhar acurado dos cineastas que adaptaram a obra, elaboraram o roteiro fílmico, e das pretensões de produtores da indústria cinematográfica, o que possibilitou nessas interações interartes, significativos entrecruzamentos entre a literatura e o cinema.

Se for certo que ambas as linguagens compartilham a tarefa de levar a fantasia, o sonho e o encanto da narrativa ao espectador, como se fossem dois "idiomas" diferentes por meio de seus processos configurativos, suas leis e também suas limitações, quando apanhados pela indústria cultural e levados os seus

\footnotetext{
${ }^{9}$ A "filmografia quixotesca" é extensa e se iniciou nos primórdios do cinema com uma tentativa pioneira de filmagem realizada pela casa Gaumont da França, datada de 1898, mas da qual não se conservaram imagens. Em caso de um maior interesse, vale a pena consultar as referências sugeridas. (Cf. MARTÍNEZ-SALANOVA SÁNCHEZ, Don Quijote de La Mancha en el cine. Disponível em: <http://www.uhu.es/cine.educacion/cineyeducacion/donquijote.htm>. Acesso em 10/09/2019. No endereço eletrônico indicado, há uma relação dos filmes adaptados para o cinema do Quixote, juntamente com os diretores, atores e até alguns cartazes dos filmes.
} 


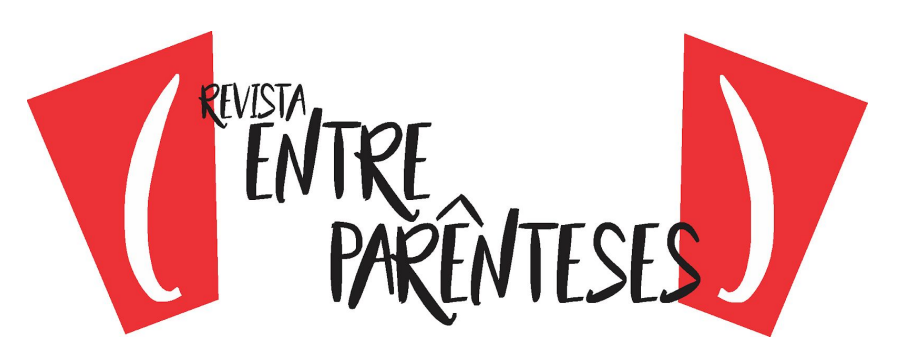

produtos ao mercado, conforme destaca Lucas (2007, p. 15), há uma tendência a "coisificá-los" e ainda degenerar a estatura humana e a integridade moral de diretores, atores, roteiristas, autores e leitores; entretanto, é possível verificar, tanto na literatura como no cinema, segundo frisa o mesmo autor, que existem alguns núcleos de resistência à massificação consumista, considerando que a arte, com seu valor estético, é atividade de natureza não utilitária, em sua essência.

No caso peculiar do Quixote, pode-se constatar que, nas versões cinematográficas que mantêm uma relação de fidelidade ao texto cervantino, houve sempre um grande esforço para transpor a obra ao roteiro cinematográfico. O foco da adaptação ficou centrado no perfil das personagens principais e nas peculiaridades de seus traços distintivos, na caracterização das feições físicas e comportamentais da dupla ímpar, na personalidade de cada um e em outros aspectos do romance, tais como o contexto espacial, temporal e social da época. Inseridos no roteiro fílmico, tais aspectos se "transfiguraram", criativamente, em imagens visuais cinematográficas concretas e significativas, sob o olhar atento do cineasta/diretor e a interpretação cênica dos atores de "carne e osso". Essa "sorte de zoom cinematográfico", como aponta Mainer (2009, p.23), deixou ver, ao lado do escrito, o imaginado visualmente e, ao lado de cada uma das personagens, a evidência e a fascinação da sua condição de criações imaginárias dispostas sempre para ocupar a escrita da prosa ou o bloco de folhas do desenhista.

As imagens do cavaleiro andante e de seu leal escudeiro se constituíram em um referencial visual fílmico que, projetado no formato da tela de cinema, recriou os milhares de páginas escritas e reproduzidas da obra em uma época distante da vivida por Cervantes, seu autor. Trata-se de uma conformação plástico/visual originada pela leitura do texto narrativo e sua posterior transposição criativa à tela cinematográfica por meio do roteiro fílmico. À vista disso, é provável que em nenhuma outra ocasião a dialética entre a realidade e a imaginação, ou o diálogo entre os seres de ficção e as formas de representação que Ihes deram forma como 


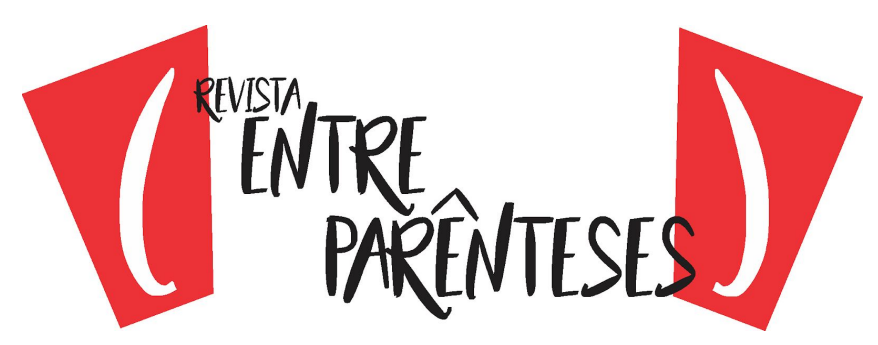

tais, segundo Heredero (2005, p.1), tenham atingido no suporte do celuloide uma concretude visual tão próxima da autorreflexão e metalinguística consciência narrativa que palpita nas páginas cervantinas onde são contadas as aventuras de Dom Quixote de la Mancha.

$\mathrm{Na}$ concepção da imagem de dom Quixote, enquanto personagem projetada pelo cinema houve, certamente, uma influência visual herdada da iconografia traçada ao longo do tempo e que gravita ainda ao redor das figuras de dom Quixote e Sancho Pança, servindo de referencial de duas diferentes atitudes perante a vida, conforme ressalva Sánchez Millán:

a visão romântica (ou pós-romântica, se assim preferir) do século XIX. Por meio dos desenhos de Gustave Doré poderemos contemplar a imagem que com maior força tem ficado de dom Quixote e, consequentemente, a que mais tem sido aproveitada não só pelo cinema, senão também pelo teatro, a dança e o balé, etc.; a imagem de um Quixote que é protagonista da gesta heroica de um sonhador fracassado que, pode chegar a ser ridículo, provocar o riso (sem esquecer que foi essa a intenção de Cervantes), mas ao mesmo tempo pouco caricaturesco, conservando certa dignidade [...] Dom Quixote é um marginalizado, uma vítima, um antecedente das personagens das novelas do século XIX, tanto pelos detalhes realistas como pelo estudo psicológico das personagens, aspectos muito importantes para o cinema. Dá-se também uma importância à paisagem com influência da pintura de história e de gênero, que também ajudará aos cineastas a pôr em cena. Além do mais, há uma reivindicação do aspecto cavalheiresco que confere uma grande nobreza à personagem, é dizer, se torna mais sério e menos ridículo. (2004, p. 141)

No contexto cinematográfico, também ambas as personagens se complementam, compartilhando características e aspectos destoantes, cujas possibilidades interpretativas permitem projetar imagens fílmicas espetaculares que, juntamente com retratar o grau de humanidade inesgotável da dupla, também podem expô-las no écran do cinema como dois seres díspar que juntos cavalgam em uma missão comum na forma de uma paródia. Assim, a própria ideia da paródia 


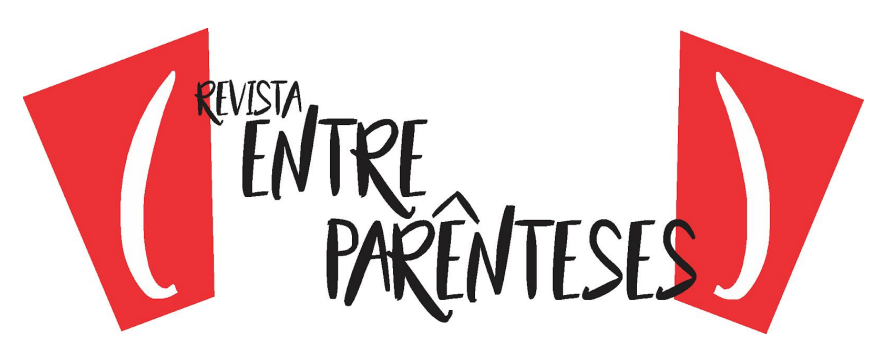

implica algumas verdades por si mesmas evidentes a respeito do processo artístico, o que se pode discriminar ou compreender da seguinte maneira:

A primeira delas é que o artista não imita a natureza, mas sim outros textos. Pinta-se, escreve-se ou faz-se filmes porque viu-se pinturas, leu-se romances, ou assistiu-se a filmes. A arte, neste sentido, não é uma janela para o mundo, mas um diálogo intertextual entre artistas. As referências intertextuais podem ser explicitas ou implícitas, conscientes ou inconscientes, diretas e locais ou amplas e difusas. Essas verdades se aplicam com igual caráter de evidência ao cinema. Diretores fazem filmes de um determinado gênero, ou "à maneira de" um certo diretor, ou de acordo com um conjunto de convenções de gênero. Independentemente dos artistas chamarem a atenção para essas influências textuais ou as tornarem obscuras, o intertexto estará sempre presente. Dom Quixote de Cervantes constitui uma matriz gerativa e um locus classicus de paródia reflexiva. Como bem sabemos, Dom Quixote refere-se às aventuras de um geriátrico e louco hidalgo, um amante da literatura de cavalaria, que se empenha em realizar o ideal literário do caballero andante. O enredo dispensa resumos, uma vez que, mesmo aqueles que nunca leram o romance conhecem o personagem seja por meio de produções populares como Man of La Mancha, seja através de adjetivos como "quixotesco" ou expressões como "lutar contra moinhos de vento". De fato, Dom Quixote é um daqueles textos que foram mundialmente disseminados sem que, na maioria dos casos, tivessem sido lidos. (STAM, 2008, p.68)

Essa imagem paródica e díspar, que envolve ambas as personagens, possui no cinema um grau de relevância dominante na visualização de uma imagem corporal que se movimenta por uma paisagem singular por onde se deslocam o cavaleiro andante e seu escudeiro, que cavalgam montados em seus respectivos quadrúpedes; de um lado, um rocim, e de outro, um jumento, e ambos os protagonistas conversando de forma animada, ora discorrendo sobre suas disparatadas aventuras, ora proseando com sensatez a respeito das peripécias dos cavaleiros andantes e, cada um do seu jeito, seguindo sua própria linha lógica de conduta, sem ceder à loucura real ou talvez suposta do outro.

$\mathrm{Na}$ configuração de dom Quixote e Sancho Pança, enquanto personagens literárias adaptadas para o cinema, isto é, na transposição do texto 


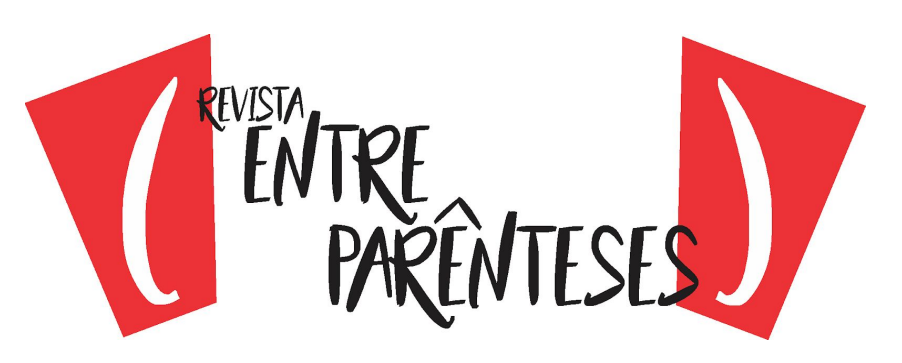

literário ao roteiro fílmico, há fatores que são determinantes, evidentemente, na concepção da imagem da dupla inigualável, assim como elementos de caráter técnico, escorço plástico e implicações que envolvem questões ideológicas. Entretanto, se o olhar atual se depara na percepção cinematográfica do Quixote visando o despertar de um interesse filológico e estético considerável, como destaca Gubern (2009, p.61), há no próprio relato do texto cervantino a presença das imagens figurativas per si com diversas funções, mas, em relação à adaptação fílmica das personagens de dom Quixote e Sancho Pança, as descrições dos aspectos físicos serão precisamente as que permitirão que o leitor e/ou receptor possa imaginar, representar ou encenar mentalmente suas aventuras à medida que lê ou vê, o que permite asseverar que o Quixote é, em certa medida, um "romance visualista" que contém descrições por vezes muito vivazes.

As descrições figurativas de dom Quixote e Sancho Pança permitem elaborar os traços de um perfil que retrata as personagens de forma visual ou icônica, por exemplo, no caso de dom Quixote. Já no Capítulo I da Primeira Parte da obra, o narrador diz que "beirava o nosso fidalgo a casa dos cinquenta. Era de compleição rija, seco de carnes, enxuto de rosto" (CERVANTES, 2012b, p. 68). Mais adiante, no Capítulo XXXV, ainda na Primeira Parte, o autor comenta do protagonista que "as pernas eram muito compridas e finas, peludas e nada limpas" (CERVANTES, 2012b, p. 490). Posteriormente, em outro momento, no Capítulo XIV, da Segunda Parte - que corresponde ao episódio do Cavaleiro do Bosque -, a descrição se complementa apontando que Dom Quixote "é um homem alto de corpo, enxuto de rosto, compridos e descarnados os membros, grisalhos os cabelos, o nariz aquilino e um tanto curvo, de bigodes grandes, negros e caídos" (CERVANTES, 2012b, p. 175). Deste modo, podemos afirmar que há no texto literário elementos descritivos suficientes para traçar ou esboçar um perfil completo de dom Quixote como personagem, que é descrito na obra e que o cinema soube aproveitar e projetar muito bem na conformação fílmica e tela de cinema. 


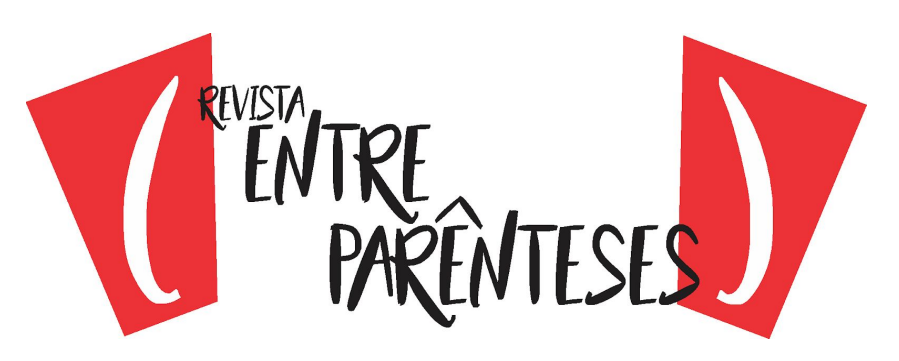

E o que dizer de Sancho Pança? Seguindo a mesma descrição figurativa, se diz no Capítulo IX da primeira parte, que o escudeiro tinha "a barriga grande, o tronco breve e as pernas finas e longas" (CERVANTES, 2012b, p. 145); também antes, em outro episódio, no Capítulo VII, da primeira parte, que narra a segunda saída de dom Quixote e o convite feito a Sancho Pança para que o seguisse com a promessa da ilha, faz-se referência ao escudeiro, que era "um lavrador seu vizinho, homem de bem (se é que esse título se pode dar a quem é pobre), mas com pouco sal na moleira" (CERVANTES, 2012b, p. 125). Em seguida, no mesmo capítulo, quando iniciam a segunda saída, o autor comenta que Sancho Pança, convertido em escudeiro, ia montado "sobre seu jumento como um patriarca, com seus alforjes e sua bota de vinho, e com muito desejo de se ver logo governador da ilha que seu amo Ihe prometera" (CERVANTES, 2012b, p. 126). Portanto, fica definido, também, o perfil chave e engraçado do escudeiro Sancho Pança que surgirá e será projetado no cinema.

Deste modo, pode-se afirmar que há dados corporais consideráveis para configurar um retrato do cavaleiro andante e do seu escudeiro não só no desenho, ilustração ou na pintura, mas também na caracterização das personagens no teatro e na projeção das imagens cinematográficas, aspectos que configuram uma plasticidade estética visível da dupla protagonista do romance.

\section{CONSIDERAÇÕES FINAIS}

Dom Quixote e Sancho Pança constituem personagens clássicas que estão entre as mais famosas da literatura universal. O impacto dessa distinção originou diferentes imagens que foram reproduzidas ao longo do tempo. No caso da versão fílmica Dom Quixote (1957) do cineasta russo Gregory Kozintsev, enquanto adaptação cinematográfica, ela teve a capacidade de interagir com um texto clássico literário monumental e de estimular as potencialidades criativas e interliterárias com 


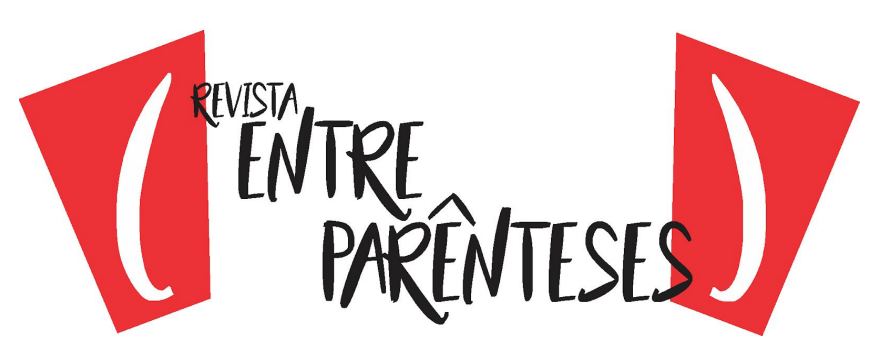

o leitor/receptor, ficando em evidência que o filme de Kozintsev transcende o enredo proposto pelo romance, assim como concebido pelo seu autor Cervantes.

Ao se estabelecerem relações comparativas intertextuais entre as duas obras, a fílmica e a literária, deve-se ter presente que, além de existir uma distância histórica entre ambas, por meio de alguns séculos e também milhares de quilômetros, houve também diferenças interculturais significativas entre a Espanha de início do século XVII e a União Soviética de meados do século XX. Portanto, entre Cervantes e Kozintsev, existem poucas conexões, por não dizer nenhuma, se olharmos dessa perspectiva ou ponto de vista. No entanto, parece ter havido interações e confluências interculturais enriquecedoras a respeito da leitura e da interpretação da imagem do Quixote no contexto cultural russo-soviético, oriundas de aproximações literárias entre a Espanha e a Rússia que coexistem como relações de "irmandade" ou de uma espécie de "fronteira comum", em cuja divisa o Quixote pode ser visto como uma imagem significativa ou até um "mito estrangeiro" de acentuada convergência e ressonância.

À vista disso, o que aproxima as duas obras não é tanto sua forma ou seu conteúdo, considerando que as aventuras do dom Quixote de la Mancha no filme foram selecionadas, modificadas e/ou adaptadas, senão o modo de transmitir o sentido em sua essência, ou seja, seu "espírito" ou sua "alma", prevalecendo na interpretação cinematográfica o ideal em pró da defesa de valores humanísticos e certa confiança no ser humano, no homem; ou seja, aspectos que tornam dom Quixote muito próximo e compreensível para a sociedade, isto é, do povo. Deste modo, tudo indica que dom Quixote, no contexto sociocultural russo, se pode considerar uma espécie de "objeto histórico", um arquétipo de ficção estética dotado de entidade própria e uma personagem amplamente politizada, cujas leituras o preencheram de ilusões por acreditar num mundo melhor e estar convencido da necessidade da utopia. 


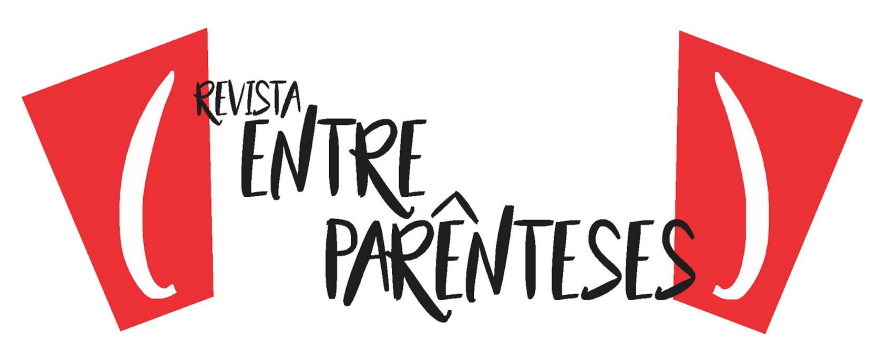

Stam lembra aqui que a obra cervantina pode ser considerada, também, como um "artefato cultural" que surgiu de um mundo mediterrâneo complexo, multicultural e multilíngue, e de uma Espanha moldada por três civilizações religiosas ao longo de séculos: a católica, a muçulmana e a judaica, esquecendo-se, muitas vezes, de que os judeus e muçulmanos da lbéria viviam em proximidade simbiótica, enquanto os católicos eram inimigos de ambos (STAM, 2008, p. 47). Em relação à versão de Kozintsev, o autor assinala que o filme pode ser visto como uma "crítica velada às contradições do stalinismo" e esclarece dizendo que o fundamentalismo impotente de Quixote é, afinal, menos perigoso do que o dos mestres do poder soviético; porém, como alguém que se vê 'além' das massas adormecidas e passivamente obedientes; assim, Quixote realmente parecer encanar a ideologia da tomada de comando do "partido vanguardista".

A versão fílmica de Kozintsev se pode considerar como sendo mais que a simples adaptação de uma obra literária para o cinema: ela carrega, por assim dizer, traços sígnicos ou imagéticos de uma concepção politizada que, de acordo com Martínez Illán (2010, p.5), poderia ser vista e lida como uma "alegoria do estalinismo" e também como a "transfiguração" de um mito nacional que concebe dom Quixote desvinculado da novela cervantina e com particularidades próprias da idiossincrasia russa. Por conseguinte, pela sua procedência, o filme de Kozintsev, em seu conjunto, não deixa de apresentar uma visão ou certa tendência "populista", acentuada por aspectos sociais contrastivos e por outros de caráter paródico advindos de alguns traços plásticos caricaturescos do ilustrador Daumier, conforme mencionado nas páginas precedentes.

$\mathrm{Na}$ concepção do filme de Kozintsev, pode-se perceber uma forte influência cinematográfica herdada da tradição fílmica russo-soviética, em particular do cinema de Eisenstein, que estará presente de forma perceptível na configuração da fotografia, enquadre fílmico, cenografia, discurso oratório, planos, ambientação e expressividade da dramaturgia cênica. O filme alude a seu tempo e o faz, também, 


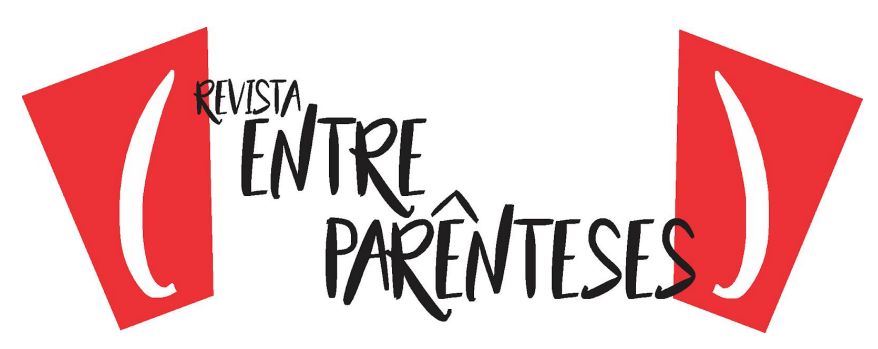

na perspectiva do seu tempo, e há necessidade de se considerar, em suas entrelinhas, o sentido simbólico/contextual que representou o "quixotismo" existente na literatura e na tradição cultural russa.

Contudo, sabe-se que, por outro lado, a obra de Cervantes representou uma leitura bem aceita e de cunho obrigatório na escola russo-soviética, fato que tornou dom Quixote conhecido e o transformou, ao mesmo tempo, em um símbolo da luta pela liberdade e igualdade contra os poderosos no período soviético. A versão cinematográfica Dom Quixote (1957) de Kozintsev, no olhar de Stam, chama a atenção para as feições cômicas e burlescas do romance, bem como para seus aspectos trágicos e filosóficos:

Da mesma forma que Kozintsev enfatizou a dimensão de classes em sua adaptação de Rei Lear [...] assim também seu Dom Quixote sublinha o conflito de classes e as ideologias. Dom Quixote, trajando uma armadura enferrujada e portando um prato de cobre na sua cabeça, faz cruzadas pela justiça em nome dos pobres e oprimidos. O filme denuncia, em especial, a crueldade dos aristocratas que torturam Dom Quixote com suas brincadeiras malévolas. A aristocrática Altisadora, por exemplo, finge estar apaixonada por Quixote, mas depois ri dele por ter acreditado que ela poderia se apaixonar por uma "vara velha e alquebrada" como Quixote. Para o público russo, supõe-se que os aristocratas desencadeiam a lembrança dos tempos dos czares. Kozintsev, ainda introduz uma crítica anticlerical fazendo com que Sancho perceba que o sacristão não faz soar os sinos da igreja para chamar os fiéis à oração, mas sim para informar sua amante, num povoado próximo, da hora de sua chegada. O personagem de Dom Quixote, por sua vez, é socialmente ambivalente. Por um lado, apesar de seu status de fidalgo, ele confronta os poderosos para resgatar os oprimidos, embora ele nunca deixe de flertar com a nobreza. Mas ele realmente socorre os fracos e indefesos; inerente à sua noção de cavaleiro andante existe um princípio democrático de igualdade e justiça. (STAM, 2008, p. 67-68)

À vista disso, por melhor que tenha sido a intenção de Kozintsev ao adaptar o Quixote para o cinema, ele fez escolhas peculiares e significativas considerando uma obra secular que possui visões universais sobre a vida e a 


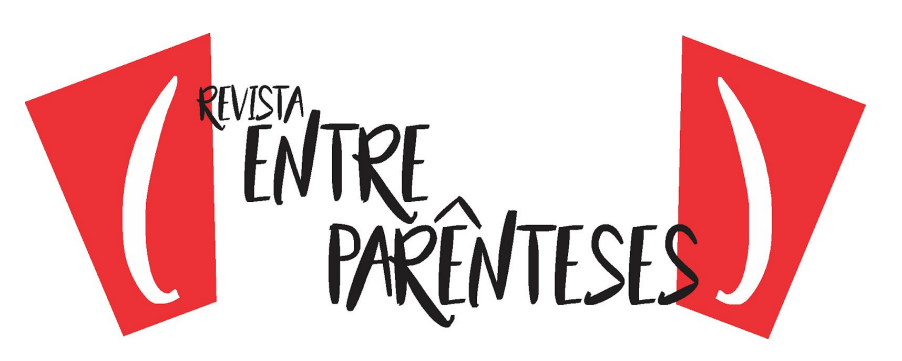

existência. Nesse sentido, mesmo que tenha havido cisões e/ou desilusões com o regime soviético, a presença de uma obra ímpar como o Quixote permitiu não haver uma perda total da esperança e da crença na utopia. Podemos supor que no filme de Kozintsev se tencionam traços de uma imagem de um "Quixote soviético", que toma uma atitude para beneficiar a comunidade e está intimamente ligado e influenciado por questões sociais; dessa perspectiva, é possível perceber o lampejo de uma "utopia quixotesca" em consonância com um coletivo de caráter social.

Considerando a perspectiva de esse olhar, Kozintsev conseguiu adaptar a obra de Cervantes para uma versão fílmica em cujo enredo cinematográfico surge a configuração de uma imagem "justiceira" de dom Quixote; isto é, o cineasta selecionou episódios do texto literário em que dom Quixote se empenha por ser resoluto e suas ações realçadas por serem entravadas por lutas, sentido de liberdade e centrado na aplicação da justiça, aspectos que vão incidir de maneira a fazer dom Quixote perder a noção da realidade e, na sua procura do bem, chegar até ocasionar o mal. Além disso, a ambientação das encenações, assim como o figurino, será traspassada pela solidão e devassidão do espírito humano, coligado às paisagens de uma região ressequida e com pouca vegetação, como a Crimeia.

É evidente que o Quixote contém linhas descritivas que permitem originar um modelo iconográfico visual, perfeitamente aplicável à estética do cinema ou a quaisquer outras formas de expressão artística, permeando as relações comparativas intertextuais que aproximam a literatura e o cinema. No entanto, as imagens dos dois protagonistas construídas de palavras e com grande plasticidade pelo estilo preciso do seu autor, passaram a ter cor e movimentos ao longo do tempo, o que originou, segundo Esteves, algumas visões e impressões advindas da sua leitura e recepção, considerando que as leituras do texto foram diferentes com o passar do tempo (ESTEVES, 2005, p. 140). 


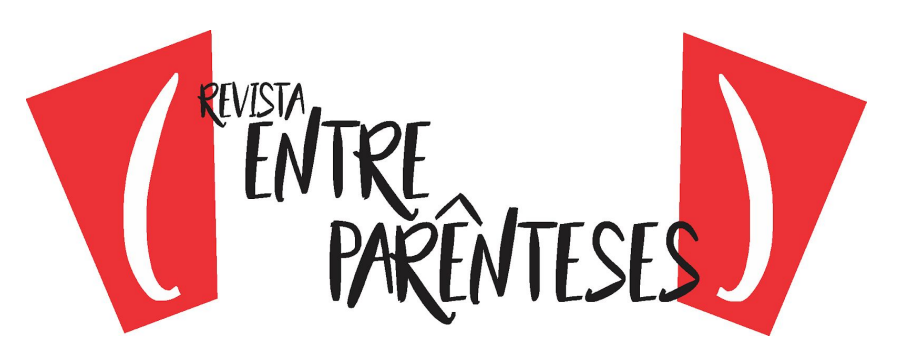

Em suma, seja uma ou outra tendência, apesar dos conflitos ou tensões que essas observações ou estudos puderam gerar, decerto, constata-se que as imagens das personagens protagonistas, ao longo do tempo, tiveram a capacidade de "sair" da respectiva obra e de se "enraizar" como imagens arquetípicas que, aos poucos, se configuraram no imaginário e memória coletiva por meio da recepção e difusão da sua leitura e da interpretação do seu texto, radicando aí, talvez, seu caráter enigmático, intertextual e até "prestidigitador" para quem porventura também leu e/ou ouviu falar a respeito da destemida dupla. Para Flores (2007, p.14), as imagens de dom Quixote e de Sancho Pança se consolidam de tal maneira que se convertem em um mito com forte apelo visual, força icônica, maleabilidade e flexibilidade textual, que podem ser observadas nas várias instâncias de como o escritor constrói suas personagens, no perspectivismo, nas omissões propositais e outras. Consequentemente, torna-se significativo considerar o Quixote como um mito no sentido de pensar que possui uma expressiva capacidade e maleabilidade para transcender ao texto original, além de conter um vigoroso apelo imagético.

Se adaptar o Quixote à tela do cinema representa um desafio quase inexequível, ao mesmo tempo, as possibilidades de realizá-lo se encontram implícitas no próprio paradoxo que representa, efetivamente, essa dificuldade, ou seja, se o cinema se constitui em expressão artística cinematográfica - e por isso mesmo chamado de "sétima arte" - há princípios e valores estéticos que, além de contrastivos e conceituais, permitem auferir novas visões e/ou imagens que vão além do Quixote literário disponibilizado por Cervantes, e que possibilitam expandir e esquadrinhar as inter-relações poliédricas entre a literatura e outras artes.

Nessa interação perspicaz, surge a imagem do "Cavaleiro da Triste Figura", atribuída a dom Quixote por meio da visão de Sancho Pança, a qual comove pela sua figuração de personagem abatida, decadente e triste, porém que ainda está em pé porque possui dignidade apesar da sua condição em declínio. Portanto, poder-se-ia ler ou interpretar como a expressão da figura de um 


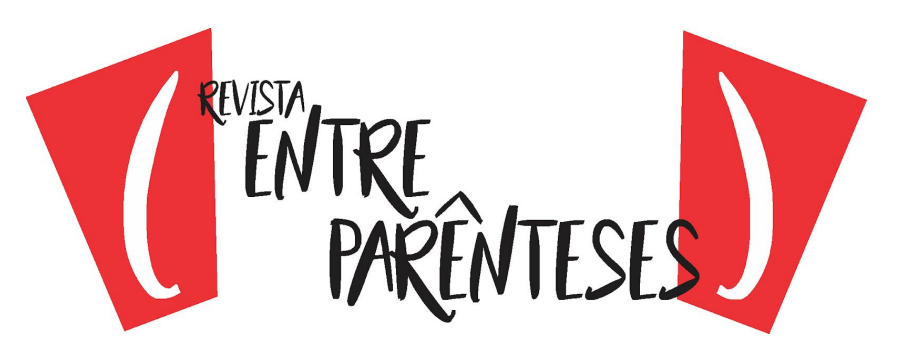

"anti-herói" que possui, todavia virtudes, alguma força física e moral, porém sua corpórea e tangível silhueta contraria de forma desfigurada a imagem e o código dos consagrados heróis cavalheirescos.

Mas, enfiado na sua armadura de latão e montado em seu rocim faminto, como frisa Galeano, Dom Quixote parece destinado à derrota e ao ridículo. Rimos dele, porém, ainda rimos muito mais com ele; contudo, essa inútil aventura literária resultou muito mais que seu projeto original, viajou mais longe e mais alto, convertendo-se no romance mais popular de todos os tempos e de todas as línguas; deste modo, conclui o autor, merece gratidão eterna "o Cavaleiro da Triste Figura", que nos salva da solenidade e do tédio (GALEANO, 2005, p. 267-268, tradução nossa).

\section{REFERÊNCIAS}

AUMONT, Jacques; MARIE, Michel. Dicionário teórico e crítico de cinema. Trad. Eloisa Araújo Ribeiro. 2. ed. Campinas: Papirus, 2006.

BAULER, Paulo. Os muitos modos de ler. In: YUNES, Eliana (Org.). Leitura pelo olhar do cinema. São Paulo: Editora Reflexão, 2013. p.15-58.

BORGES, Jorge Luis. Una conferencia recobrada sobre Don Quijote. CASA DE LAS AMÉRICAS, n.265, p. 131-137, out.-dez., 2011. Disponível em: <http://www.casa.cult.cu/publicaciones/revistacasa/265/salvadas.pdf> Acesso em: 12 abr. 2015.

CALVINO, Italo. Por que ler os clássicos? Trad. Nilson Moulin. 2. ed. São Paulo: Companhia das Letras, 2007.

CARDOSO, Luís Miguel Oliveira de Barros. Literatura e cinema: dissídios e simbioses. In: NASCIMENTO, Evandro; OLIVEIRA, Maria Clara Castellões; SILVA, Teresinha V. Zimbrão da (orgs.). Literatura em perspectiva. Juiz de Fora: Editora da UFJF, 2003. p. 61-76.

CERVANTES, Miguel de. Don Quijote de La Mancha, Edición del IV Centenario. Real Academia Española, Asociación de Academias de la Lengua Española. São Paulo: Brasil, 2004. 


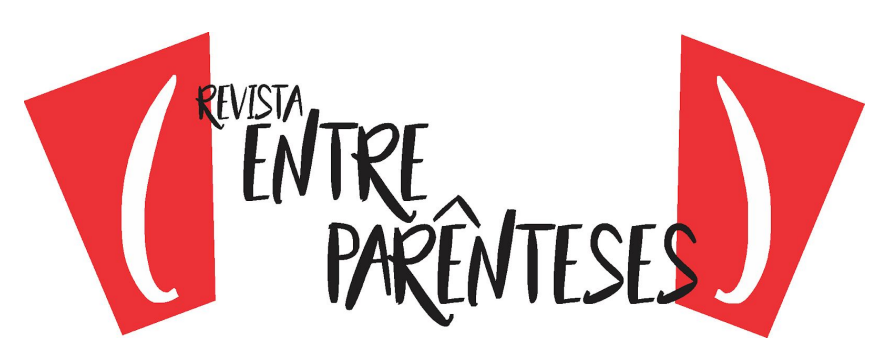

CERVANTES, Miguel de. O engenhoso fidalgo D. Quixote de La Mancha. 2. ed. Trad. Sérgio Molina. São Paulo: Ed. 34, 2012.

CLÜBER, Claus. Inter textus / inter Artes / inter media. Aletria, Belo Horizonte, v.14, n.1, p. 11-41, jul.-dez, 2006.

DÍEZ, Luis Mateo. Algunas Meditaciones. Leer - Los 400 años del Ingenioso Hidalgo, Madrid, Año XX, n. 158, p.174-175, diciembre, 2004.

EGIDO, Aurora. A memória e o Quixote. In: VIEIRA, Maria Augusta da Costa (org.). A letra e os caminhos. São Paulo: Edusp, 2006.

ESTEVES, Antônio Roberto. Dom Quixote: quatro séculos de luta contra os quiméricos moinhos do tempo. In: TROUCHE, André Luiz Gonçalves; REIS, Lívia de Freitas (orgs.). Dom Quixote: Utopias. Niterói: EdUFF, 2005. p.138-145.

FLORES, Célia Navarro. Da palavra ao traço: Dom Quixote, Sancho Pança e Dulcinéia del Toboso. 2007. 296 f. Tese (Doutorado em Língua Espanhola e Literatura Espanhola e Hispano-americana) - Faculdade de Filosofia, Letras e Ciências Humanas, Universidade de São Paulo; São Paulo, 2007.

GALEANO, Eduardo. Don Quijote de las paradojas. EDUCERE, vol. 9, n.29, p. 267-268, abr.-jun., 2005. Disponível em: http://www.saber.ula.ve/handle/123456789/19959> Acesso em: 10 mar. 2018.

GUBERN, Román. Una lectura cinematográfica del Quijote. In: HEREDERO, Carlos F. (org.). Espejos entre ficciones - El cine y el Quijote. Madrid: Ministerio de Cultura, Sociedad Estatal de Conmemoraciones Culturales, 2009. p. 61-74.

JOHNSON, Randal. Literatura e cinema, diálogo e recriação: o caso de Vidas Secas. In: PELLEGRINI, Tânia (et al). Literatura, cinema e televisão. São Paulo: SENAC, 2003. p. 37-59.

HEREDERO, Carlos F. (org.). Espejos entre ficciones - El cine y el Quijote. Madrid: Ministerio de Cultura, Sociedad Estatal de Conmemoraciones Culturales, 2009.

HEREDERO, Carlos F. Don Quijote desde la butaca. EL CULTURAL, 6 de janeiro de

2005.Disponívelem:<http://www.elcultural.es/version_papel/LETRAS/11084/El_Quijo te_y_el_arte_nuevo>. Acesso em: 16 abr. 2018.

KOZINTSEV, Grigori (direção). Don Quixote. Rússia: Paragon Multimedia, 1957. 


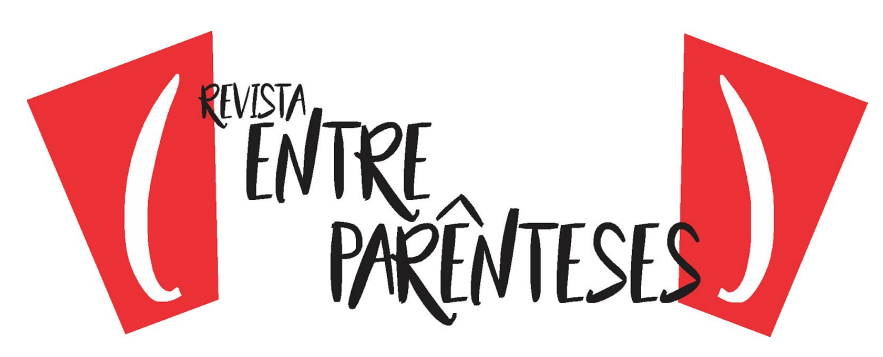

KRAUSE, Gustavo Bernardo. Verdades quixotescas: ensaios sobre filosofia de Dom Quixote da Mancha. São Paulo: Annablume, 2007.

LUCAS, Fábio. I. Prefácio. In: BRITO, José Domingos de. Literatura e cinema. v. 4. São Paulo: Novera, 2007. p. 9-20.

MAINER, José-Carlos. El Quijote: Plaza de todas las artes. In: HEREDERO, Carlos F. (org.). Espejos entre ficciones - El cine y el Quijote. Madrid: Ministerio de Cultura, Sociedad Estatal de Conmemoraciones Culturales, 2009. p. 17-28.

MARTÍNEZ ILLÁN, Antonio. Don Quijote en el cine soviético: Kozintsev y Kurchevski. ÁREA ABIERTA, $\mathrm{n}^{\circ}$ 27, noviembre 2010. Disponível em: <http://revistas.ucm.es/index.php/ARAB/issue/view/ARAB101033>. Acesso em: 23 nov. 2016.

NASCIMENTO, Magnólia Brasil Barbosa do. Entre a realidade e a ficção, quatrocentos anos depois. In: TROUCHE, André Luiz Gonçalves; REIS, Lívia de Freitas (orgs.). Dom Quixote: Utopias. Niterói: EdUFF, 2005. p. 113-129.

PALMA, Glória Maria (org.). Literatura e Cinema: A Demanda do Santo Graal \& Matrix/Eurico o Presbítero \& A Máscara do Zorro. Bauru-SP: EDUSC, 2004.

PAZ, Octávio. Signos em rotação. Trad. Sebastião Uchoa Leite. 3. ed. São Paulo: Perspectiva, 2012.

ROJO, Sara. Imagem, imaginação, história: La Odisea de César Brie. In: CORNELSEN, Élcio Loureiro; VIEIRA, Elisa Amorim; SELIGMANN-SILVA, Márcio (orgs.). Imagem e Memória. Belo Horizonte: Rona Ed. FALE/UFMG, 2012. p. 323-333.

SAMAIN, Etienne (org.). Como pensam as imagens. Campinas-SP: Ed. da UNICAMP, 2012.

SÁNCHEZ MILLÁN, Alberto. La imagen de Don Quijote en el cine. In: EGIDO, Aurora (org.). Los rostros de Don Quijote: IV Centenario de la publicación de su primera parte. Zaragoza: IberCaja, Obra Social y Cultural, 2004. p.137-158.

SANTAELLA, Lucia. Palavra, imagem \& enigmas. Revista USP- Dossiê Palavra I Imagem, São Paulo, n.16, p. 36-51, dez.-jan. - fev., 1992/1993. 


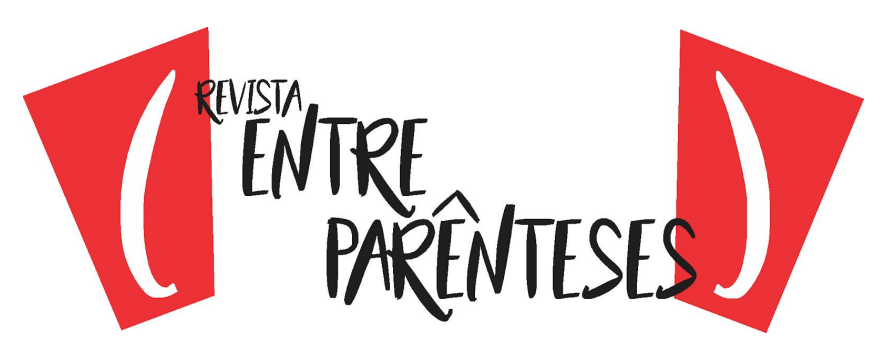

STAM, Robert. A literatura através do cinema: realismo, magia e a arte da adaptação. Trad. Marie-Anne Kremer e Gláucia Renate Gonçalves. Belo Horizonte: Editora UFMG, 2008.

VARGAS LLOSA, Mario. Una novela para el siglo XXI. In: Don Quijote de La Mancha, Edición del IV Centenario. Real Academia Española, Asociación de Academias de la Lengua Española. São Paulo: Brasil, 2004. p. XIII-XXVIII.

VIEIRA, Maria Augusta da Costa. A narrativa engenhosa de Miguel de Cervantes. São Paulo: Edusp, 2012 a.

VIEIRA, Maria Augusta da Costa. Apresentação de D. Quixote. In: CERVANTES, Miguel de. $O$ engenhoso fidalgo D. Quixote de La Mancha. 2. ed. Trad. Sérgio Molina. São Paulo: Ed. 34, 2012b. 